Article

\title{
Sustainable Public Procurement Policies on Promoting Scientific and Technological Innovation in China: Comparisons with the U.S., the UK, Japan, Germany, France, and South Korea
}

\author{
Xiaoli Wang ${ }^{1,2}$, Yun Liu ${ }^{3, *}$ and Yanbing Ju ${ }^{1}$ \\ 1 School of Management and Economics, Beijing Institute of Technology, Beijing 100081, China; \\ 76018111@bit.edu.cn (X.W.); juyb@bit.edu.cn (Y.J.) \\ 2 School of Economics and Management, Zhongyuan University of Technology, Zhengzhou 451191, China \\ 3 School of Public Policy and Management, University of Chinese Academy of Sciences, Beijing 100049, China \\ * Correspondence: liuyun@ucas.ac.cn; Tel.: +86-10-8825-6625
}

Received: 22 May 2018; Accepted: 15 June 2018; Published: 22 June 2018

check for updates

\begin{abstract}
In many countries, sustainable public procurement is a powerful tool to reflect on national strategic intentions and promote scientific and technological innovation. Based on the perspective of an institutional structure, we filtered out the core policies. Using policy bibliometrics, we analyzed Chinese public procurement policies on promoting scientific and technological innovation, revealed policy-making characteristics, and concluded that the Ministry of Finance should appropriately decentralize the policy-making work to other relevant agencies of the State Council. This article compares the main policy tools from four dimensions in China, the U.S., the United Kingdom, Japan, Germany, France, and South Korea. We issued these pertinent strategies: establishing the vendor database for small and medium enterprises, developing a grade system and the post-evaluation system, formulating detailed implementation methods for high-tech products (services), and carrying out classification management for imported products. For sustainable public procurement policies on promoting scientific and technological innovation, this article provides an effective reference to organize the agencies and formulate the detail measures. This article's research framework could be applied to analyze other industry policies.
\end{abstract}

Keywords: public procurement policy; scientific and technological innovation; comparison

\section{Introduction}

On 1 April 2014, the Open Work Group of UN Sustainable Development Goals (SDGs) declared that "sustainable public procurement" was the first action plan launched. On 1 January 2016, the 17th SDGs of the 2030 Agenda for Sustainable Development-adopted in September 2015 at a historic UN Summit by world leaders of the UN's 193 Member States-officially came into force [1]. The SDGs 12.7 (2017) stated that they would "promote public procurement practices that are sustainable in accordance with national policies and priorities [2]", and called on environmental protection and energy conservation, protecting workers' rights, taking care of backward areas, and conforming to national strategy and security when conducting Public Procurement (PP). SDGs 12.7 would expand the environmental and social benefits brought by government expenditures, and promote the global sustainable development and economic growth transformation into a high-speed track [3]. Coming to "value money", PP behavior has been playing a policy function to promote sustainable development.

In many countries, the PP system is a powerful tool reflecting national strategic intention and promoting Scientific and Technological (S\&T) innovation [4]. It is also an important policy to support 
domestic enterprises' innovation and development from the demand side [5]. In China, PP means government procurement. As an effective system to promote S\&T innovation, the role of PP policy has been widely recognized [6].

In China's import and export trade in November 2016, the top three countries or regions were the European Union (EU), the U.S., and the Association of Southeast Asian Nations (ASEAN) [7]. Germany, the UK, and France are the top three countries in the EU, Japan and South Korea are the top two countries in ASEAN. This article chooses the above six countries to conduct a comparative analysis with China.

This article introduces the literature from four dimensions: energy-saving and environmentally friendly products, S\&T Small and Medium Enterprises (SMEs), high-tech products, and domestic products. We will explain the four dimensions in Section 2.2.2.

\subsection{Promoting Energy-Saving and Environmentally Friendly Products}

Sustainable PP focuses on promoting the investment, development, and production of energy-saving and environmentally friendly products [8].

In China, fiscal fund supporting projects preferentially procure energy-saving and environmentally friendly products and phase out low-efficiency products [9]. Mandatory procurement is implemented for products that meet the standards for energy-saving effects and performances [10]. Some of China's policies stipulate specific and operable terms for energy-saving and environmentally friendly products, such as the Opinions on Implementation on Government Procurement Energy-Saving Products [11].

The U.S. federal procurement agency has formulated the green procurement plan, which establishes federal environmental enforcement agencies, supervises green PP, and submits annual reports [12]. The Federal Acquisition Regulation stipulates ways of procuring eco-type products and utilizing recycled materials $[13,14]$ —ones that have the least impact on people's health and the environment [15]. For green PP, the federal government pays particular attention to formulating standards and developing a variety of methods (e.g., minimum price, life cycle cost, price concession, etc.) [16].

The European Union (EU) has formulated the Guidelines for Green Procurement, which explicitly requires implementing environmental protection policies. It has also issued green procurement standards for 18 classes of products and services [17]. Most of the member states implemented the National Action Plans (NAPs) for green PP and formulated specific implementation measures [18]. The mechanism of developing green procurement varies among the EU member states, and there are mainly two types: centralized procurement represented by the United Kingdom (UK) and independent procurement represented by Germany [19].

Japan encourages manufacturers to develop products that have less impact on the environment, and to enhance environmental awareness in PP [20]. To build an environmentally friendly and sustainable society eventually, Japan influences manufacturers of environmentally friendly products based on demand [21].

South Korea has expanded its green product market through mandatory procurement programs to prevent resource waste and environmental pollution, and to achieve sustainable development [22]. The scope of eco-products in the green procurement program complies with environmental label certification or green certification in South Korea [23].

\subsection{Promoting SET SMEs Development}

To promote SMEs development, especially S\&T SMEs, PP is an important government issue on sustainable economic development strategy.

For preferential treatment of SMEs, China has formulated many policies, such as SME recognition, equal treatment, reserving shares, reviewing preferences, encouraging SME consortium, 
subcontracting, and training SMEs [13]. China also provides support policies, such as credit guarantees, performance bonds, payment deadlines, and payment methods [24].

The U.S. has formulated preferential policies to encourage SMEs to participate in PP, including reservation contracts and separation contracts, stipulating procurement ratios [25], offering quotations [26], providing loan guarantees, establishing specialized service agencies [27], accrediting procurement representatives and experts, issuing ability certificates, and establishing electronic supply systems [28].

By improving legislation and publicizing rules for PP, the EU provides action guidelines for SMEs to participate in and reduce SMEs' entrance barriers [29]. The UK has introduced policies such as "Pre-commercial Procurement of Innovation [30]", "Small Business Research Initiative [31]", and "Forward Commitment Procurement [32]." Germany has stipulated that SMEs have priority in bidding for public projects, which could split for SMEs easy to participate in [33]. To encourage SMEs to participate in procurement activities for high-tech products in France, the government reserves shares [34], prioritizes, splits the contract [35], allows bids without contract guarantees and advance payments, and has set up a dedicated service department [36].

Japan has focused interiorly on SMEs' protection in the form of laws, and has supported domestic SMEs through an exception clause in the Agreement on Government Procurement (GPA) [37]. Japan's main policies include lowering the entry threshold, splitting the contract, reserving the proportion, and assisting in exploring foreign government procurement markets [38].

South Korea has actively promoted the identification of SMEs' technical products, and requires all public agencies to procure them with priority [39]. South Korea pays certain R\&D expenses for SMEs' new technology development, and guarantees that the institutions supported by fiscal funds procure these products [40]. SMEs' patent fees are supported by the exemption's system, and are funded for applications on board [41].

\subsection{Promoting High-Tech Products (Services)}

High-tech products (services) involve outputs for the key industries supported and protected by the government. PP of high-tech products (services) aim at fulfilling social functions to promote national economic and social development [42].

China has formulated certain policies, such as giving priority to domestic high-tech companies, introducing innovation-oriented technical indicators [43], price concession in bidding, sharing the risks of R\&D and consumers (including price subsidies and preferential loans), setting procurement ratios [44], forward ordering or first procuring, and procuring first major technical equipment [45].

For high-tech products' PP, the U.S. has given priority to domestic manufacturers [46] and has protected the domestic high-tech product market by raising the entry threshold [47]. It has encouraged emerging enterprises to participate in the development of major strategic technologies, and has designed a larger competitive space in the PP system [48].

$\mathrm{PP}$ is tilting toward high-tech products in the EU, thereby supporting the development of high-tech industries [49]. Whether or not it is due to being a signatory at the GPA, EU members have a series of policies and regulations that limit imported high-tech products (services), and encourage procurement from the region [50]. The UK implements the Innovation Procurement Plan and regards innovation as a key requirement for large-scale equipment and capital planning [51]. In Germany, PP policies on innovative technologies and solutions aim to share the risks of R\&D and consumers [52]; innovation-oriented technical indicators are introduced in PP processing to encourage new technologies' utilization [53].

Through local procurement ratio restrictions [54], high tariffs on foreign products [55], and preferential treatment for high-tech products (services) [56], Japan has promoted the development of high-tech industries. 
In South Korea, fiscal supporting agencies give priority to procurement of high-tech products [57], and have acquired all publicly-owned equipment, such as domestic high-speed trains and nuclear power stations, preferring to procure domestic products if they are expensive [56].

\subsection{Promoting Domestic Products}

It is common practice for all countries to maintain their own interests and protect their own industries in accordance with the GPA.

In China, the PP has focused on achieving the state's policy goals for economic and social development [58], including the protection of key domestic industries [59]. For domestic products, the government has implemented priority procurement, minimum procurement share, and compulsory procurement (in certain areas) in fiscal funding projects [60]. China has stopped implementing some policy documents that conflict with the GPA, and has accordingly formulated some policies consistent with the agreement [61]. To protect key industries, Chinese policies include implanting quota restrictions on international bidding, raising tariffs, reviewing imported products, and importing products attached with technology transformation or services or compensation [62].

According to domestic product PPs in the U.S., the laws include the Buy American Act, the Reciprocal Tariff Act, the Berry Amendment Extension Act, and the Federal Acquisition Regulation. The legislative purpose of the Buy American Act is "Supporting and protecting American industry and investment capital [47]". Even though the U.S. is a member of the GPA, its exception clause still applies to the unopened procurement project and all of its non-members [63].

For EU public facilities, the EU products' procurement proportion must reach more than $50 \%$, and its products can obtain priority if their prices are not above 3\% [64]. Most EU members require that PP products must meet EU's market standards, which are often difficult for foreign companies [65]. In the UK, the fiscal supporting institutions must procure high-tech products such as computers and communications equipment from their domestic companies [66]. In France, aviation, railway, communications, and other departments give priority to domestic products [67]. For more than $€ 5$ million worth of projects or more than $€ 200,000$ worth of goods and services, Germany stipulates that procurement must be within the EU [68].

Japan has made full use of domestic policies and various GPA exception clauses to protect domestic industries [56]. Its internal policies include stipulating the domestic product's procurement proportion, enjoying special depreciation benefits in case of procuring domestically-made computers, enjoying subsidies, long-term and low-interest loans, and deferring repayment loans in case of procuring domestically-made machinery and equipment [37]. Japan's foreign product policies include high tariffs on foreign procurement and restrictions on the GPA exception clause [38].

South Korea has encouraged preferential procurement for domestic products, limits on the number of international tenders, splits contracts, and excludes international suppliers to protect domestic suppliers [56].

\subsection{International Comparison}

We retrieved the Web of Science SSCI with keywords related to "public/government procurement" and "international/cross-border/cross-country comparison", and received the following information.

Most cross-border comparative research on PP involve domestic and foreign markets, companies, and products [69]. Research on PP between the U.S. and South Korea shows that the market has traditionally been exclusive from foreign suppliers, and there are several preferential regulations and policies for domestic firms to award procurement contracts $[41,57]$.

Some research involved the organizational structure and management system of typical industrialized countries such as the U.S., Germany, and South Korea, and pointed out their superiority [70]. Other research shows PP efficiency based on 25 European Countries [71]; international experiences on health care PPPs (Public-Private Partnership) among 16 countries (10 EU members, Canada, Australia, Chile, Mexico, South Africa, and Lesotho) [72]; market regulatory efforts on rare 
diseases and orphan drugs in six EU members [73]; and discussion on how fiscal resources' rational allocation can be conducive to low procurement prices and promotion of sustainable procurement policies [74].

There is not much independent and integrated comparative research among the four dimensions on energy conservation and environmental protection, S\&T SMEs' development, and high-tech products (services); we regard the EU as an entity. By retrieving the Web of Science SSCI, we obtained the following research: analysis of the construction industry in the Czech Republic and Austria [75]; developed countries' PP policies on technological development [76]; and procurement of three inpatient medical devices in Italy and Spain [77]. There is other related research: PP was mostly used to induce new technologies via direct public technology procurement programs as well as R\&D procurement [69]; there are preferential policies on SMEs' independent innovation and strengthening business training for Australia, Canada, the U.S., Argentina, Brazil, China, India, Indonesia and Kazakhstan [78] (there is none for EU state members); and in Japan and South Korea, policies on S\&T SMEs' development and electronic PP were implemented [79].

There is less comparative research on international PP policies, especially those that discuss the four dimensions.

\subsection{Research Review}

Based on the above literature, scholars had done a lot of in-depth research on energy-saving and environmentally friendly products, S\&T SMEs' development, and high-tech products and domestic products. However, there are two deficiencies:

(1) A lack of systematic research on policy tools.

Most PP policy research that promotes S\&T innovation is on only one of the four dimensions mentioned above, and fewer when compared to all of them [61].

(2) A lack of international comparison research from multiple dimensions.

For PP policies that promote S\&T innovation, there is little research on international comparative analysis from multiple dimensions; thus, there is lack of a strong analytical basis for the same [69].

In summary, there is adequate research on different fields, but less comprehensive and systematic PP policy research on promoting S\&T innovation at the international level.

\section{Data Collection and Methods of Analysis}

\subsection{Research Framework}

First, this article classifies relevant Chinese policy texts, narrows the policy analysis scope, and improves the accuracy. Second, utilizing the policy bibliometrics method [80], we analyze effective policy texts from the four dimensions of policy-making time, policy-making agency, chief agency, and collaboration agencies. International comparison is also from four dimensions: energy-saving and environmental protection products, S\&T SMEs' development, high-tech products (services), and domestic products. Finally, based on the conclusions, we issued corresponding policy suggestions. The article's research framework is shown in Figure 1. 


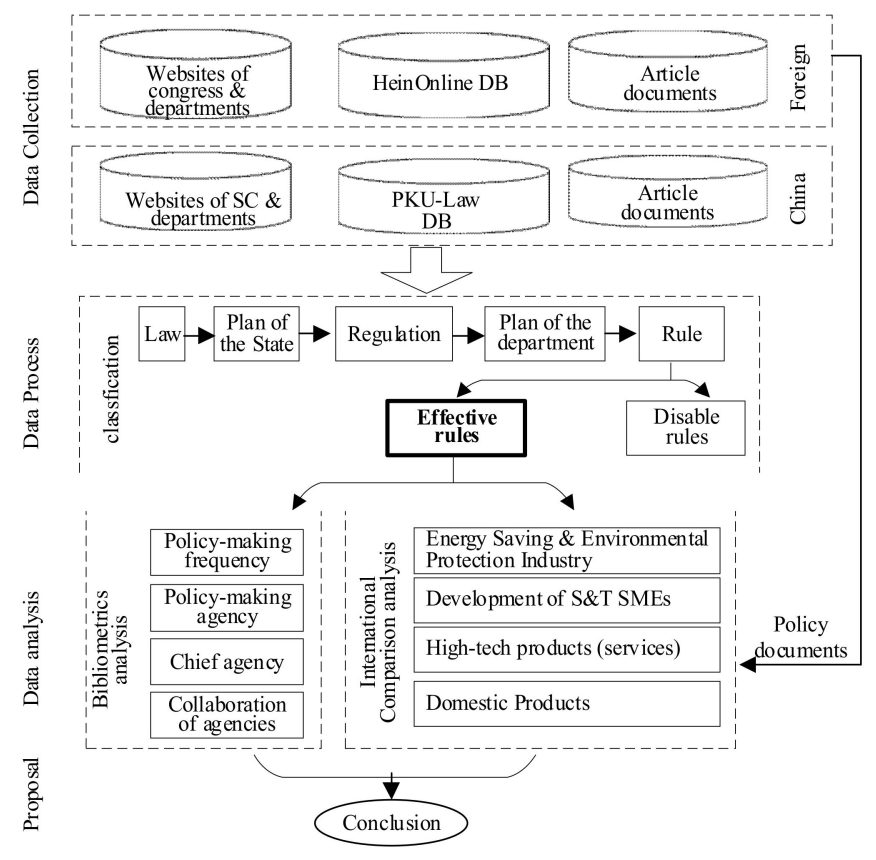

Figure 1. Research Framework.

\subsection{Data Collection}

\subsubsection{Data Source}

In this article, China's various policy texts come from three aspects. The first is the "PKULaw" (http: / / www.pkulaw.cn/) — the database of laws and regulations; the second is the official website of the State Council (SC) or its departments; and the third is related article documents. "PKULaw" is a one-stop search platform providing intelligent legal information, jointly launched by the Law Information Center of Peking University and PKU Yinghua Technology Co., Ltd. (Beijing, China). "PKULaw" was built by the Law Department of Peking University in 1985, and has the most mature, professional, and advanced comprehensive legal information retrieval system in China. Due to the concentration of PKULaw, it is the main source of policy collection in this article, supplemented by the official website for SC and government departments.

The above-mentioned countries' policy texts come from three categories: the HeinOnline-Database (http://heinonline.org/HOL/Welcome), websites of the national congress and government departments, and the analytical texts of relevant articles.

For PP policies on promoting S\&T innovation in this article, the analysis objects included laws and regulations at a national level in China. The research period for main laws and regulations is 1 January 2003-30 December 2017. It is worth noting that the Government Procurement Law was implemented in 1 January 2003.

\subsubsection{Retrieval Strategy and Results}

In processing retrieval, we classified policy documents into four categories. Each policy category contained a number of policy tools (policy measures), and a policy tool is in the form of multiple terms (articles). The relationships among the four categories are as follows: Policy document $\supset \cap$ Policy category $\supset \bigcap$ Policy Tool (Policy measure) $\supset \bigcap$ Policy term (Data record).

This article mainly involves the classification of policy tools and the selection of keywords. Our search strategy is as follows (shown in Figure 2): 


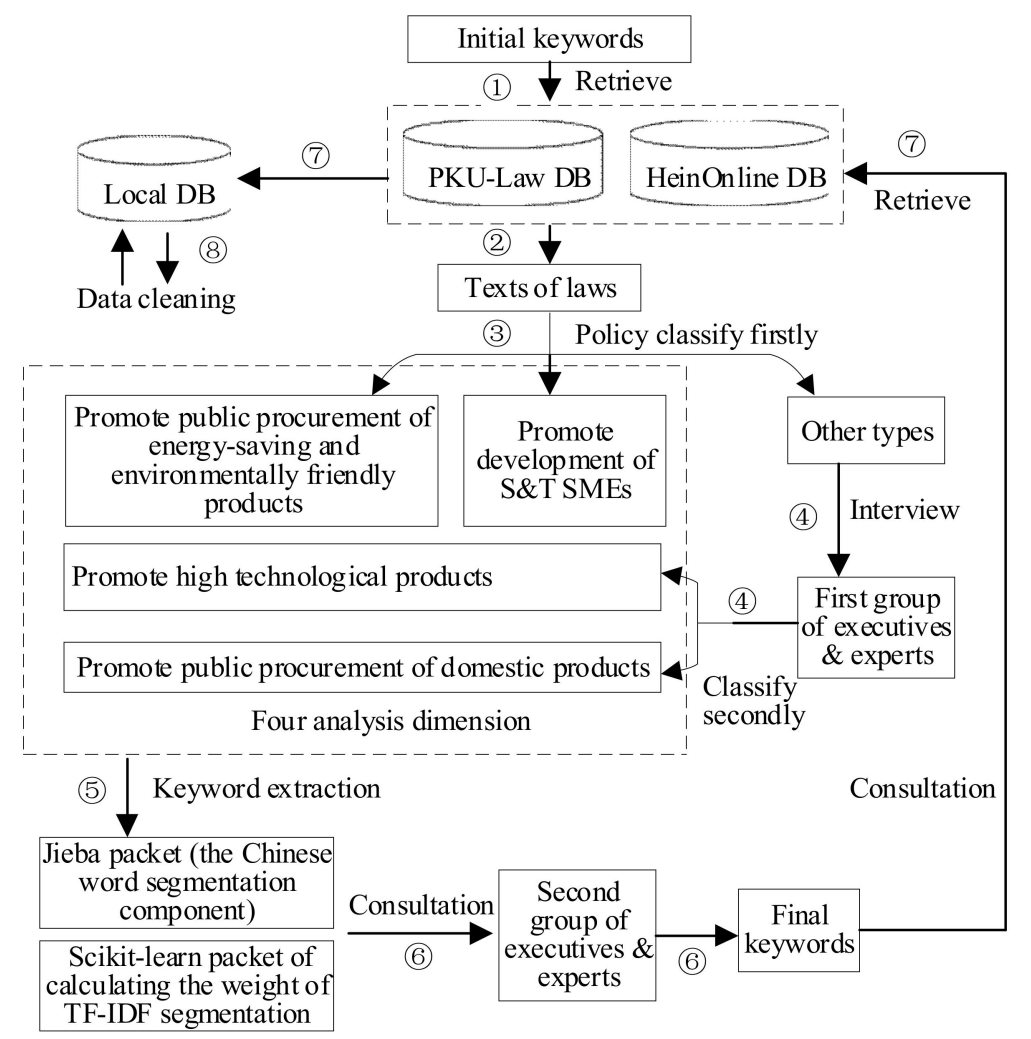

Figure 2. Retrieval Strategy and Results. Notes: The ordinal number of the figure corresponds to the following steps (China).

(1) Chinese policies' retrieval strategy and results

Step 1. According to the article's theme, we chose "government procurement"/"public procurement"/"procurement" + "science and technology" / "innovation" /"technological innovation"/"scientific and technological" / S\&T" as the initial key words to retrieve national level laws.

Step 2. We retrieved the laws at the national level and obtained eight texts shown in Table A1.

Step 3. According to the theme of sustainable PP, we classified the policy texts into three categories: energy-saving and environmentally friendly products, development of S\&T SMEs, and other types of policies [1].

Step 4. We continued to classify "other types of policies" in Step 3. We interviewed executives and experts from the Institute of Science and Development of CAS, and the Government Procurement Promotion Center of Zhongguancun in Beijing. Based on their interviews, we classified the "other types of policies" into two categories: high-tech products and domestic products. We finally divided the policy tools into four categories.

Step 5. For keyword extraction for the final four categories, we chose the TF-IDF method (Term Frequency-Inverse Document Frequency [81,82]), which is a common weighting method for information retrieval and data mining. In the Python program, we used the Jieba packet (the Chinese word segmentation component) to segment the legal texts. Next, we calculated the weight for the TF-IDF segmentation by using the Scikit-learn packet [83-85], which is a simple and effective tool for data mining and data analysis. Finally, we obtained 112 key words with high weightage (shown in Table A2).

Step 6. We sought expert consultation for the key words. By visiting institutions such as the Beijing Municipal Science and Technology Commission, and the Shenzhen Municipal 
Government Procurement Center, we sought the opinions of executives and experts, and confirmed the final keywords for each classified retrieval, as shown in Table A2.

Step 7. We retrieved and obtained related policy tools according to the keywords. Then, we obtained 925 data records from the local database, which involved 58 policy documents (see Table 1).

Step 8. On completing the data cleaning, we obtained 785 data records, which involved 34 policy documents (Table 1). We then established a Chinese PP policy document database on promoting S\&T innovation. Data fields included a release date, policy title, policy-making agency, class for policy tool, and context of policy tool.

(2) Retrieval strategy and results of the above-mentioned six countries:

The same method was used to retrieve the policies for the above-mentioned six countries. The main legal documents retrieved are shown in Tables A7-A13.

\subsection{Research Methods}

For quantitative analysis, this article utilized the policy bibliometrics method, which is a quantitative analysis method used to identify the policy's external characteristics [86]. We conducted a comparative analysis of policy-making frequency and policy-making agencies, which is important background information. The agency's policy-making frequency represents the degree of participation in making policies. By analyzing policy-making agencies, we can focus on that agency's status as a leading or collaborative role in the policy-making processing.

For qualitative analysis, we utilized the text mining and comparative analysis methods. The text mining method was utilized in extracting keywords and identifying policy dimensions and tools; its application was in data collection processing [87], as shown in Figure 2. We examined policy tools' differences with the comparative analysis method.

Through comparative analysis of the policies between China and the above-mentioned six countries, we put forward some PP policy suggestions to promote S\&T innovation.

\section{Institutional Structure of Chinese PP Policy for Promoting S\&T Innovation}

\subsection{Classification of the Policies}

There are five different classes of policies implemented in China. The National People's Congress (NPC) enacts laws; SC and its departments issue various plans; SC promulgates various regulations; and SC departments promulgate various rules, as shown in Table 1.

For the formulators of PP policies that promote S\&T innovation, the main subject at the highest level is NPC. The Chinese Communist Party Central Committee (CCPCC) enacts the plan at the national level, representing its important position in making decisions. Various plans have no legal effectiveness but are of great guiding significance for the various regulations and rules. Regulations are formulated by the SC. Its various departments set forth state department regulations and department rules. Their effectiveness relationship is illustrated as follows: Law $>$ Plan of State $>$ Regulation $>$ Plan of department $>$ Rule, as shown in Table 1. 
Table 1. The Class and Level of Chinese Policy.

\begin{tabular}{ccccc}
\hline No. & Class & Agency & $\begin{array}{c}\text { Number of } \\
\text { Effective Records }\end{array}$ & $\begin{array}{c}\text { Number of Invalid Legal } \\
\text { Documents }\end{array}$ \\
\hline 1 & Law & NPC & 8 & 0 \\
2 & Plan of the State & CCPCC, SC & 5 & 2 \\
3 & Regulation & SC & 2 & 0 \\
4 & Plan of department & Department of SC ${ }^{2}$ & 0 & 2 \\
5 & Rule & CCPCC, SC, Department of SC & 5 \\
\hline \multicolumn{2}{c}{ Subtotal } & 34 & 9 \\
\hline
\end{tabular}

Notes: ${ }^{1}$ There are four abolished policies and a policy related to abolished policies, so the abolished policies' total number is five (shown in Table A6). ${ }^{2}$ There are four disabled plans, including two plans for the 11th Five-Year (Ministry of Science and Technology), two plans for the 12th Five-Year (SC) (shown in Tables A3 and A5). Therefore, there are nine policies separate from the others.

(1) Law

In this article, the direct laws include only the Tendering and Bidding Law of the People's Republic of China (hereafter referred to as the Tendering and Bidding Law) and the Government Procurement Law of the People's Republic of China (hereafter referred to as the Government Procurement Law).

In April 1999, the Ministry of Finance (MOF) passed the Interim Measures for the Administration of Procurement Management, which is the first regulation on PP in China. In 1999, the NPC Standing Committee promulgated the Tendering and Bidding Law. Based on the Interim Measures for the Administration of Procurement Management, the Government Procurement Law came into force on 1 January 2003; it is the basis law for Chinese PP. According to the Chinese, the actual situation, and relevant advanced countries' experiences, the Government Procurement Law was amended in 31 August 2014. The Tendering and Bidding Law and the Government Procurement Law constitute main laws on promoting S\&T innovation, as shown in Table A1.

Table A1 shows six other laws that offer provisions for PP; they play important roles in promoting S\&T innovation. Some examples are the Law of the People's Republic of China on Promotion of Small and Medium Enterprises and the People's Republic of China Energy Conservation Law.

(2) The State Plan

The state plans mainly involve the Five Year Plan and the medium- and long-term plans by the SC. Once the new Five-Year Plan is released, the old one is disabled. For PP policies on promoting S\&T innovation, the plans involve two aspects: one is on The National Economic and Social Development; the other is on S\&T innovation, as shown in Table A3.

(3) Regulation

In this article, SC regulations refer to the Regulation on the Implementation of Tendering and Bidding Law, and the Regulation on the Implementation of the Government Procurement Law; they are legal regulations for PP and their bidding was formulated by the SC; they are also subordinate to the law. They are shown in Table A4.

(4) The Department Plan

In this article, department plans mainly involves plans for S\&T innovation. The 11th Five-Year Plan and the 12th Five-Year Plan for scientific and technological innovation that were released by the Ministry of Science and Technology (MOST) are part of department plans. The 13th Five-Year Plan released by the SC is part of the state plan. They are shown in Table A5. 
(5) Rule

For specific problems relating to jurisdiction or industry fields, single departments or joint departments of SC can enact relevant rules, which are mainly management methods and opinions.

Laws, state plans, regulations, and department plans act as base functions in the PP policy system on promoting S\&T innovation, and do not involve practical policy tools. In this article, the focus is on related policy documents that serve as effective rules in the 13th Five-Year period. Practical policy tools involve guidelines, standards, and behaviors. Therefore, we chose 34 practical policies after sorting through the retrieved data, in order to obtain a more accurate analysis scope. They are shown in Table A6.

\subsection{Date Node Analysis of Policy-Making}

As for the revision of some policies, we took the latest release date as the criterion. In addition, we took the year of the release date for measurement and analysis. This is shown in Figure 3.

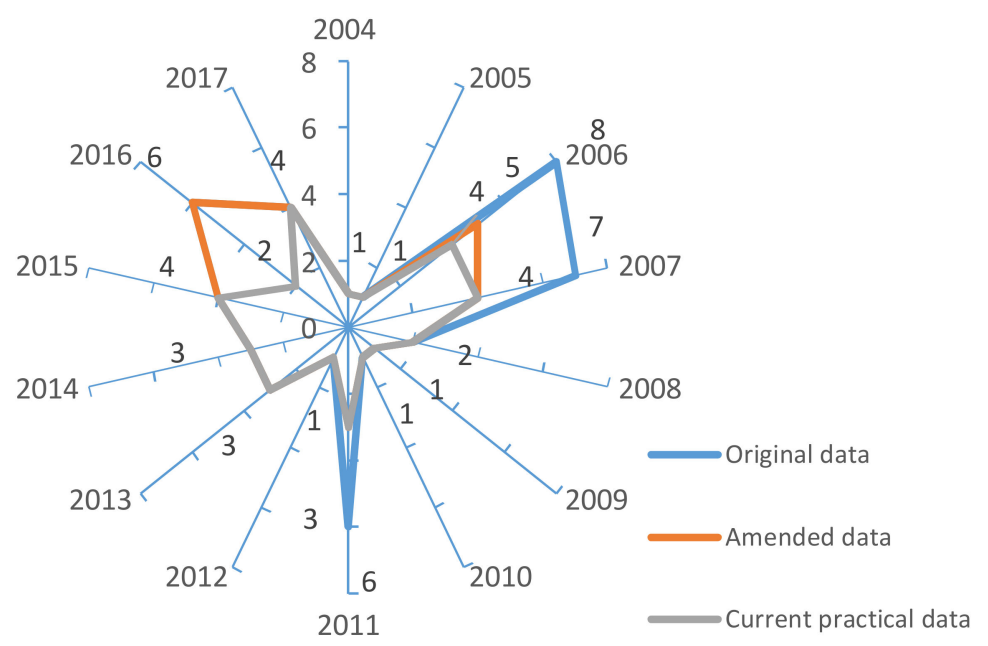

Figure 3. The Annual Number Distribution of Policies from 2004 2017. Note: The amended data does not include abolished and disabled policies. The current practical data excludes the disabled plans of the "11th Five-Year" and "12th Five-Year". The follow-up is the same.

We found that in Figure 3:

(1) The highest number of policies were in 2006 and 2007. In the period of the 11th Five-Year, China paid more attention to independent intellectual property, carried out the transformation of S\&T achievements, put forward the identification and management of national independent innovation products, and then formulated series of S\&T policies, including PP policies on promoting S\&T innovation.

(2) In 2007, China carried out negotiations on entry into the GPA and submitted its application and initial bid to the WTO Secretariat for the first time. In 2008-2012, the formulation of policies were considerate, so the number was low.

(3) In 2011, there were two state plans released on the 12th Five-Year and one document released on abolishing the previous policies, so only three policies were selected for analysis. In 2016, there were four state plans released on the 13th Five-Year, so only three policies were selected for the analysis.

(4) There are changes between the amended data and the original data in 2006, 2007, and 2011, due to abolished policies and disabled policies. There are changes between the amended data and the practical data in 2006 and 2011, due to disabled plans. 
(5) Between 2004 and 2017, the highest number of practical policies was in 2006. It was between 1-4 years for the other years.

\subsection{Analysis of Policy-Making Agencies}

\subsubsection{Analysis of Agency's Participation Frequency}

There are 16 agencies that participate in the formulation of PP policies for promoting S\&T innovation. The total participating frequency of agencies is 70; MOF and SC have a frequency of more than 10. Seven other departments have a frequency of one. This is shown in Figure 4.

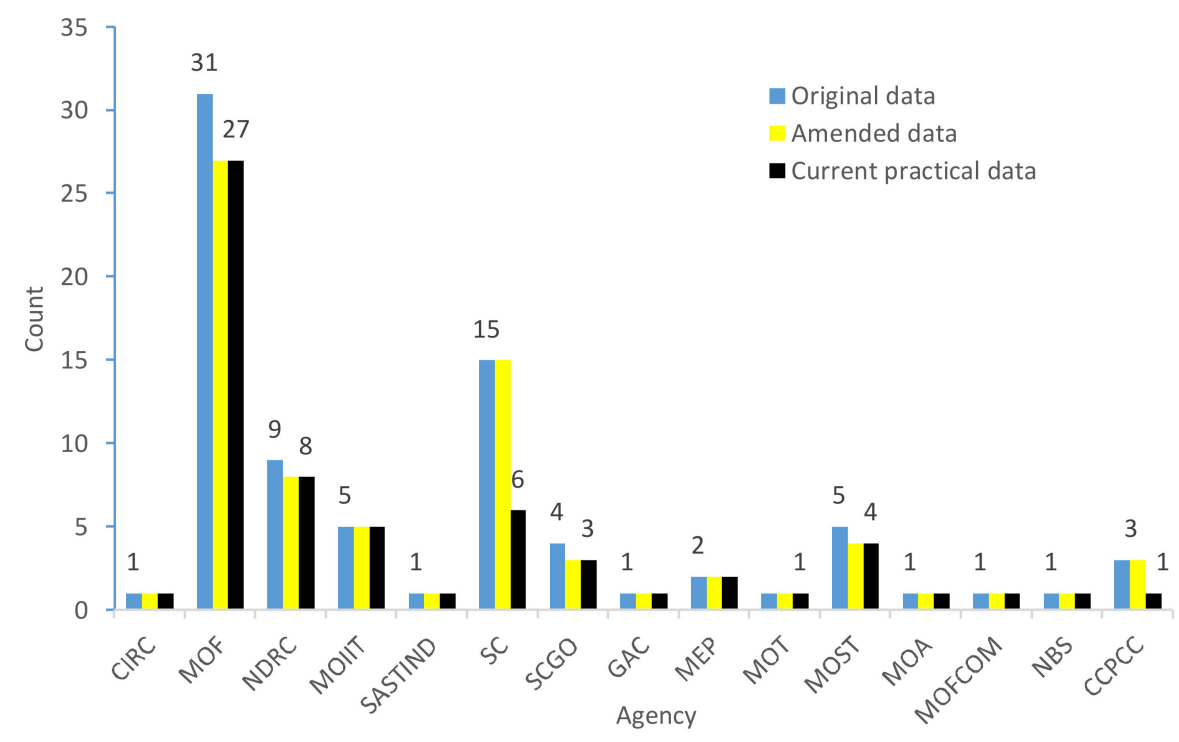

Figure 4. The Number Distribution of Various Agencies (Including Participation) in 2004 2017. Notes: The agencies' abbreviations are listed as follows: CCPCC—Central Committee of the Chinese Communist Party; CIRC —China Insurance Regulatory Commission; GAC-General Administration of Customs; MEP-the Ministry of environmental protection; MOA-Ministry of Agriculture; MOF-Ministry of Finance; MOFCOM-Ministry of Commerce; MIIT-Ministry of Industry and Information Technology; MOST-Ministry of Science and Technology; MOT-Ministry of Transport; NBS-National Bureau of Statistics; NDRC—National Development and Reform Commission; SASTIND—State Administration of Science. Technology and Industry for National Defense; SC—State Council. SCGO-General Office of State Council.

For practical policies, we found that (Figure 4):

(1) With regard to agencies' participation frequency, MOF has the most (27); next is NDRC (8); the others are under 5 ; and the average is 4.2 .

(2) Excluding the plans for the Five-Year, there are six practical policies for SC and one for CCPCC.

(3) The number of participating agencies is 14. Participation frequency for the four agencies is above average; this shows that participation from SC departments must be strengthened.

\subsubsection{Analysis of Chief Agency}

For chief policy-making agencies in 2004-2017, the number distribution is shown in Figure 5. For practical policies, we look at Figure 5:

(1) As for the chief agencies, MOF's leading times are the highest (21); the next is SC (4); the average is 3.7; and the other agencies are under average. 
(2) The chief agencies' number is 9. There are four agencies whose leading times are above average. SC contains more than 60 agencies, including administrators, committees, and directly-affiliated institutions. Figure 5 shows that is not a high enough lead for SC's agencies to formulate policies.

(3) As the chief policy-making agency, MOF is far above the other departments.

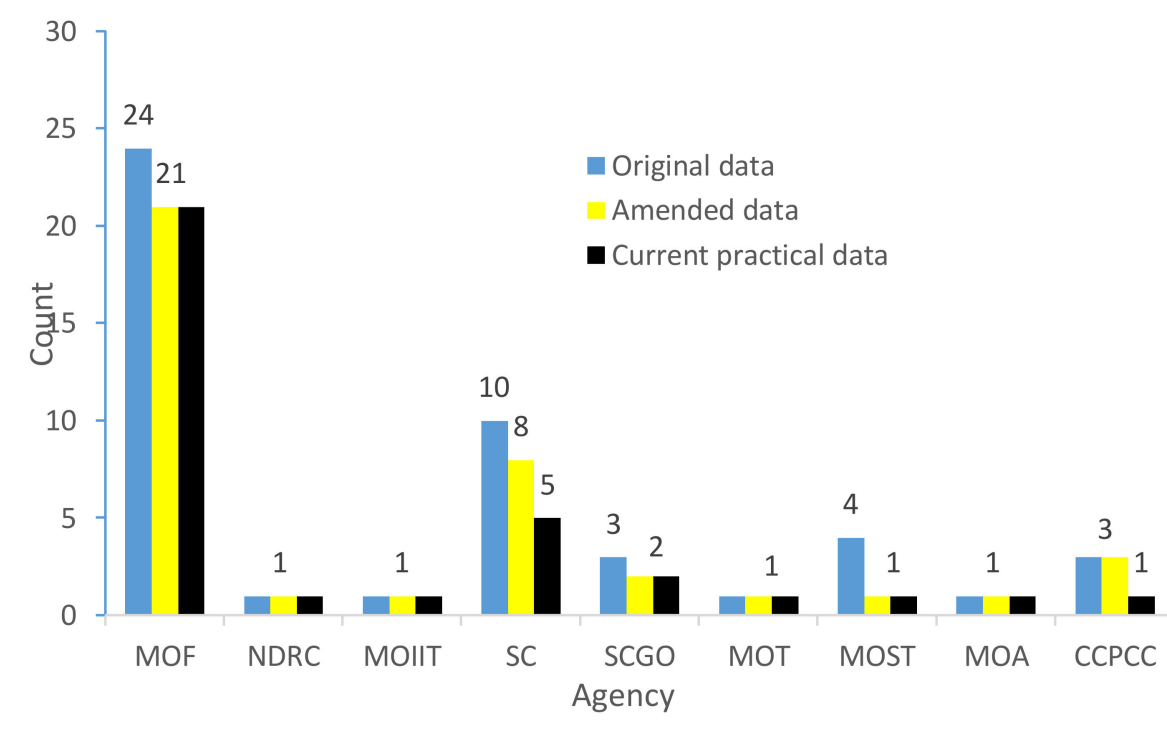

Figure 5. The Number Distribution of the Chief Policy-making Agencies in 2004-2017.

\subsubsection{Analysis of Agency's Collaboration}

Among the policy-making agencies, the status of an agency's collaboration is shown in Figure 6.

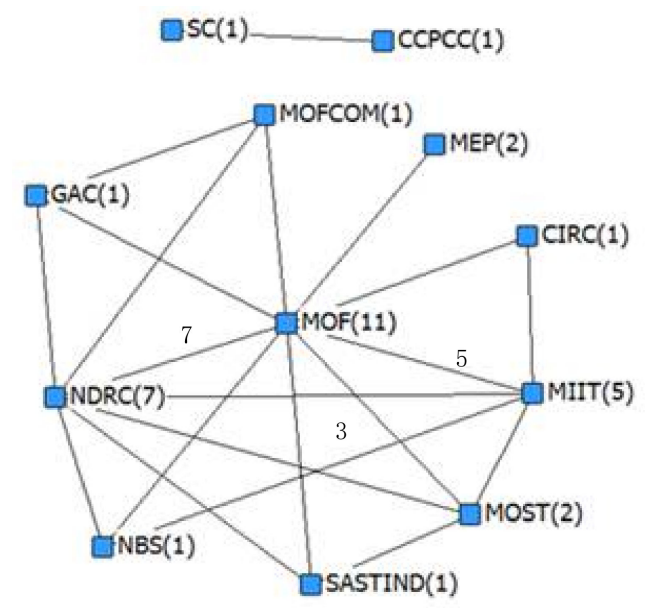

Figure 6. Collaboration Network of Policy-making Agencies. Notes: Figures in parentheses indicate the number of policies formulated by the agency collaborating with others; the numbers on the line between departments indicate the number of collaborations among each other.

Figure 6 shows the following collaboration information in policy formulation:

(1) In the sample data, 12 agencies collaborated in formulating policies. The total number of participating agencies is 14 (Figure 4 ) and the ratio is $85.7 \%$, which is a relatively high percentage, but the ratio is not high compared to overall SC agencies.

(2) For collaborating with other agencies, MOF's policy-making number is the largest (11), followed by the NDRC (7), then followed by MIIT (5), and other agencies at 1 . 
(3) The total number of collaborations is 34 and the average is 2.83 . The collaboration number of $75 \%$ agencies is less than the average.

(4) The collaboration number is 7 between MOF and NDRC, 5 between MOF and MIIT, and 3 between NDRC and MIIT. The rest of the agencies' collaboration number with each other is less than 3.

(5) The collaboration network between CCPCC and SC is isolated from the other agencies.

Formulating PP policies that promote S\&T innovation requires the participation of several agencies. However, it has been noted that in general, a large number of agencies are not actively involved. The vast majority is below average with regard to policy making (either as a participant or as the chief). Agencies participate less and there is not much at stake for them. In addition, if the policy does not have a large coverage, its effectiveness may be discounted. In order for a PP policy on promotion of S\&T innovation in the country, it is important that the dominance of MOF is reduced. On the international stage, developed countries need to realize that MOF has intervened too much in PP policy formulation and a deep misunderstanding about government subsidies is highly possible. The MOF should appropriately decentralize policy-making to other relevant agencies in order to eliminate these unnecessary misunderstandings.

\section{Comparison of Relevant Policies between the Six Countries and China}

For PP polices on promoting S\&T innovation, there are lots of successful experiences and practices across the globe. It is the consensus and common practice to promote S\&T innovation and industry development. Through the formulation and implementation of PP policies, developed countries have accelerated their technological progress and S\&T innovation, and have enhanced their competitiveness.

PP policies on promoting S\&T innovation follow four classes: (1) energy-saving and environmentally friendly products, (2) development of S\&T SMEs, (3) high-tech products, and (4) domestic products. On sorting out policies, China has learnt from the developed countries, adopting the above-mentioned four measures.

\subsection{Promoting Energy-Saving and Environmentally Friendly Products}

For energy-saving and environmental protection products, policies include formulating a green products list, setting the minimum green procurement share, establishing a special green procurement agency [10], and drawing a national action plan on green procurement [12]. The policies implemented by the EU and its member states are most effective in this area. As Table 2 shows, different countries focus their attention on the issue in different ways.

Table 2. Comparison in Promoting Energy-Saving and Environmental Protection Industry in Different Countries.

\begin{tabular}{|c|c|c|c|c|c|c|c|c|}
\hline No. & Policy Tools & $\mathrm{CN}$ & US & UK & $\mathrm{DE}$ & FR & $\mathrm{JP}$ & KR \\
\hline 1 & Priority procurement of energy-saving products & $\sqrt{ }$ & $\sqrt{ }$ & $\sqrt{ }$ & $\sqrt{ }$ & $\sqrt{ }$ & $\sqrt{ }$ & $\sqrt{ }$ \\
\hline 2 & Mandatory procurement of energy-saving products & $\sqrt{ }$ & & & & & & \\
\hline 3 & Provide procurement guide (directory) & $\sqrt{ }$ & $\sqrt{ }$ & $\sqrt{ }$ & $\sqrt{ }$ & $\sqrt{ }$ & $\sqrt{ }$ & \\
\hline 4 & Develop a government quantitative standard for renewable energy & & $\sqrt{ }$ & $\sqrt{ }$ & $\sqrt{ }$ & $\sqrt{ }$ & & \\
\hline 5 & Establish a government green procurement agency & & $\sqrt{ }$ & $\sqrt{ }$ & & & $\sqrt{ }$ & $\sqrt{ }$ \\
\hline 6 & Develop green procurement standards & $\sqrt{ }$ & $\sqrt{ }$ & $\sqrt{ }$ & & & & $\sqrt{ }$ \\
\hline 7 & Price concession & $\sqrt{ }$ & $\sqrt{ }$ & & & & $\sqrt{ }$ & \\
\hline 8 & Reserving procurement share & & & $\sqrt{ }$ & $\sqrt{ }$ & $\sqrt{ }$ & & \\
\hline 9 & Implementation of environmental labeling (certification) system & $\sqrt{ }$ & $\sqrt{ }$ & $\sqrt{ }$ & $\sqrt{ }$ & $\sqrt{ }$ & $\sqrt{ }$ & $\sqrt{ }$ \\
\hline 10 & Appraisal of government agencies' green procurement & & & $\sqrt{ }$ & $\sqrt{ }$ & $\sqrt{ }$ & $\sqrt{ }$ & \\
\hline 11 & Procurement and use of new energy vehicles & $\sqrt{ }$ & $\sqrt{ }$ & $\sqrt{ }$ & $\sqrt{ }$ & $\sqrt{ }$ & $\sqrt{ }$ & $\sqrt{ }$ \\
\hline
\end{tabular}


Table 2 shows that first policy tool is used by all the countries, while the third, seventh, ninth, and tenth policy tools are used less. This indicates that the mentioned countries rely on market forces to promote energy-saving and environmental protection products. There is also very strong national awareness in the U.S., the UK, and Japan on energy saving and environmental protection. In contrast, South Korea has the least number of policies, and mainly focuses on guidance. China's energy saving and environmental protection relies on government promotion.

\subsection{Promoting SET SMEs Development}

To promote S\&T SME development, the policies include reserving procurement share, contract splitting, price concessions, low interest loans, and other means [13]. As shown in Table 3, countries focus their efforts on different approaches.

Table 3. Comparison in Promoting the Development of S\&T SMEs in Different Countries.

\begin{tabular}{|c|c|c|c|c|c|c|c|c|}
\hline No. & Policy Tools & $\mathrm{CN}$ & US & UK & DE & FR & JP & KR \\
\hline 1 & Reserving procurement share & $\sqrt{ }$ & $\sqrt{ }$ & $\sqrt{ }$ & $\sqrt{ }$ & $\sqrt{ }$ & $\sqrt{ }$ & $\sqrt{ }$ \\
\hline 2 & Contract split (subcontract) & $\sqrt{ }$ & $\sqrt{ }$ & $\sqrt{ }$ & $\sqrt{ }$ & $\sqrt{ }$ & $\sqrt{ }$ & \\
\hline 3 & Price concessions or fiscal compensation & $\sqrt{ }$ & $\sqrt{ }$ & $\sqrt{ }$ & $\sqrt{ }$ & $\sqrt{ }$ & & $\sqrt{ }$ \\
\hline 4 & Guarantee loan or no guarantee loan & $\sqrt{ }$ & $\sqrt{ }$ & & & $\sqrt{ }$ & & $\sqrt{ }$ \\
\hline 5 & Special management agency & $\sqrt{ }$ & $\sqrt{ }$ & $\sqrt{ }$ & & & & $\sqrt{ }$ \\
\hline 6 & Appointed experts or free training & $\sqrt{ }$ & $\sqrt{ }$ & $\sqrt{ }$ & & $\sqrt{ }$ & & \\
\hline 7 & Certification of competency & $\sqrt{ }$ & $\sqrt{ }$ & & & & & \\
\hline 8 & Establish SMEs information system & $\sqrt{ }$ & $\sqrt{ }$ & & $\sqrt{ }$ & & & \\
\hline 9 & Simplify the prequalification process & & & $\sqrt{ }$ & & $\sqrt{ }$ & & \\
\hline 10 & Intellectual property management & & & $\sqrt{ }$ & & & & $\sqrt{ }$ \\
\hline 11 & Information exchange platform & $\sqrt{ }$ & & & & & $\sqrt{ }$ & $\sqrt{ }$ \\
\hline 12 & Low interest loans & $\sqrt{ }$ & & & & & & \\
\hline 13 & Encourage participation in green procurement initiatives & $\sqrt{ }$ & $\sqrt{ }$ & $\sqrt{ }$ & $\sqrt{ }$ & $\sqrt{ }$ & $\sqrt{ }$ & $\sqrt{ }$ \\
\hline 14 & Help to open up foreign markets & $\sqrt{ }$ & & & & & $\sqrt{ }$ & \\
\hline
\end{tabular}

Table 3 shows that the first policy tool is used in all countries, but the seventh, ninth, twelfth, and fourteenth policy tools are not widely used. The used policy tools in China are the highest, and only the ninth and tenth policy tools have not been adopted. However, China is paying more attention to intellectual property issues. There are fewer policy tools in Japan and Germany, and only five policy tools are used.

\subsection{Promoting High-Tech Products (Services)}

To promote high-tech products (services), policies mainly include the mandatory procurement of high-tech products (services) and the introduction of innovation-oriented technological indicators in bidding [56]. The countries have different advantages, key development industries, and standards of high-tech products (services) [50]. In addition, they take care of domestic standards to support related key industries. These countries also focus on different modes (Table 4). 
Table 4. Comparison in Promoting High-tech Products (Services) in Different Countries.

\begin{tabular}{|c|c|c|c|c|c|c|c|c|}
\hline No. & Policy Tools & $\mathrm{CN}$ & US & UK & DE & FR & JP & KR \\
\hline 1 & Priority of domestic enterprises & $\sqrt{ }$ & $\sqrt{ }$ & $\sqrt{ }$ & $\sqrt{ }$ & $\sqrt{ }$ & $\sqrt{ }$ & $\sqrt{ }$ \\
\hline 2 & Introduce innovation-oriented technological indicators in bidding & & & $\sqrt{ }$ & $\sqrt{ }$ & $\sqrt{ }$ & $\sqrt{ }$ & \\
\hline 3 & Design larger competition space & & $\sqrt{ }$ & & & $\sqrt{ }$ & & \\
\hline 4 & Develop import procurement catalog & $\sqrt{ }$ & & & & $\sqrt{ }$ & & \\
\hline 5 & Price concession in bidding & $\sqrt{ }$ & $\sqrt{ }$ & $\sqrt{ }$ & & & & $\sqrt{ }$ \\
\hline 6 & Sharing the risks of $R \& D$ and consumers ${ }^{1}$ & $\sqrt{ }$ & & $\sqrt{ }$ & $\sqrt{ }$ & $\sqrt{ }$ & & \\
\hline 7 & Set the procurement ratio & & & & & & $\sqrt{ }$ & \\
\hline 8 & Long-term order & $\sqrt{ }$ & & $\sqrt{ }$ & & $\sqrt{ }$ & & \\
\hline 9 & First procurement and first order of high-tech products (services) & $\sqrt{ }$ & & & & & & \\
\hline 10 & The first (set) major technological equipment & $\sqrt{ }$ & & & & & & \\
\hline
\end{tabular}

Table 4 shows that the first policy tool is used by all the countries, while the third, seventh, ninth, and tenth policy tools are less used. The ninth and tenth policy tools belong to only China's policy. It shows that all countries attach great importance to promoting high-tech products (services). However, since innovation is not easily accepted and grasped, there are not many policies. Chinese supportive policies are the most because China is at the S\&T innovation catching-up stage, and policies on promoting high-tech products (services) meet the development of the time.

\subsection{Promoting Domestic Products}

Policies on promoting domestic products include mainly setting the minimum procurement share and establishing compulsory procurement rules [60]. It is a general method to restrict imported product suppliers and support domestic products such as setting a higher bidding threshold and bidding costs, restricting the amount of international bidding, and raising tariffs [62]. GPA members may adopt the above-mentioned methods for procurement projects in the unopened scope and in facing non-GPA members [63]. Meanwhile, GPA members also restrict opening entities and provide exceptions in GPA attachments as shown in Table 5.

Table 5. Comparison in Promoting Domestic Products in Different Countries.

\begin{tabular}{|c|c|c|c|c|c|c|c|c|}
\hline No. & Policy Tools & $\mathrm{CN}$ & US & UK & $\mathrm{DE}$ & FR & JP & KR \\
\hline 1 & Set the minimum procurement share of domestic products & $\sqrt{ }$ & $\sqrt{ }$ & $\sqrt{ }$ & $\sqrt{ }$ & $\sqrt{ }$ & $\sqrt{ }$ & $\sqrt{ }$ \\
\hline 2 & Mandatory procurement rules for domestic products ${ }^{1}$ & $\sqrt{ }$ & $\sqrt{ }$ & $\sqrt{ }$ & $\sqrt{ }$ & $\sqrt{ }$ & $\sqrt{ }$ & \\
\hline 3 & Restriction on opening entities of $\mathrm{PP}^{2}$ & $\sqrt{ }$ & $\sqrt{ }$ & $\sqrt{ }$ & $\sqrt{ }$ & $\sqrt{ }$ & $\sqrt{ }$ & $\sqrt{ }$ \\
\hline 4 & Set exception clauses in the GPA attachment & & $\sqrt{ }$ & $\sqrt{ }$ & $\sqrt{ }$ & $\sqrt{ }$ & $\sqrt{ }$ & $\sqrt{ }$ \\
\hline 5 & Set higher bidding threshold and bidding costs & & $\sqrt{ }$ & $\sqrt{ }$ & & & $\sqrt{ }$ & $\sqrt{ }$ \\
\hline 6 & International tender limitation & $\sqrt{ }$ & $\sqrt{ }$ & $\sqrt{ }$ & & $\sqrt{ }$ & & $\sqrt{ }$ \\
\hline 7 & Increase tariffs & $\sqrt{ }$ & $\sqrt{ }$ & & & & & \\
\hline 8 & Restrict on suppliers of imported products & $\sqrt{ }$ & $\sqrt{ }$ & $\sqrt{ }$ & $\sqrt{ }$ & $\sqrt{ }$ & $\sqrt{ }$ & $\sqrt{ }$ \\
\hline 9 & Imported products with additional measures ${ }^{3}$ & $\sqrt{ }$ & $\sqrt{ }$ & & & & & \\
\hline 10 & Formulate list of priority import and banned import & $\sqrt{ }$ & $\sqrt{ }$ & $\sqrt{ }$ & $\sqrt{ }$ & $\sqrt{ }$ & $\sqrt{ }$ & $\sqrt{ }$ \\
\hline
\end{tabular}

As Table 5 shows, the first, third, eighth, and tenth policy tools are used by all the countries, while the seventh and ninth policy tools are used less. It is more prudent to make policies that protect domestic products by increasing tariffs and transferring intellectual property. Second, the U.S. covers all the policy tools, which are more comprehensive; China uses two fewer policy tools than the U.S. due to it not having formally joined the GPA, nor setting a relatively high bidding threshold. The policy tools used in Germany are the lowest. 


\section{Discussion}

We have analyzed Chinese PP policies that promote S\&T innovation and compared them with those of six countries. There are many successful experiences and some defects.

\subsection{Promoting Energy-Saving and Environmentally Friendly Products}

Due to mandatory procurement features for energy-saving and environmentally friendly products, there are some problems that need to be considered: (1) the cost of entering the list is too high; (2) the certification and audit of the product takes a long time; and (3) the product supplier may deliberately raise the price.

At present, excessively emphasizing on the priority of the Environmental Labeling Products List (The List) results in poor operability because there are a lot of products not on the list. In addition, some policies are too general and lack unified support and operating details; thus some procurers are not willing to cooperate with the policies' implementation.

Public policies on energy-saving and environmental protection run an important function for the PP. To promote the energy-saving and environmental protection industry, the green PP policy should play an important role. Therefore, the government should formulate and improve the Green Public Procurement Law and its provisions, enhance the information circulation system of the green PP, establish and improve the supervision mechanism, further strengthen the management system, and increase the enthusiasm of green product manufacturers by utilizing taxes, price subsidies, and fiscal subsidies.

\subsection{Promoting SET SMEs Development}

There are two kinds of problems with Chinese policies for promoting S\&T SME development. The first kind includes poor operability on reserving procurement share; overlap between price deduction policy and other policies; and the less effective credit guarantee in supporting SMEs. The other is as follows: undistinguishing products' S\&T content and quality and indistinguishing support for SMEs. One feasible way is to organize and establish a database of SME vendors, which will dynamically update their identification according to different industry standards and real-time data. The relevant departments should formulate "Catalogues of SME Innovative Products and Services" and the SMEs' identification standards of high-tech products (services), which have the priority to be procured under the same condition.

\subsection{Promoting High Technological Products}

In general, there are many PP policies that promote high-tech products (services), but there are some problems: (1) The procurers are not willing to take risks due to the high-tech products (services) not being mature enough; (2) the procurers prefer to choose mature products (services) rather than trying to reduce the maturity of high-tech products (services); and (3) the high-tech products (services) have not entered into large-scale production and application-they do not have competitive advantages in terms of cost and price.

Concerning the aspect of ordering procurement, there are two problems: (1) There is no effective division of the demand scope; and (2) there is no effective collection, selection, and revision for the demand. Therefore, we should establish a grading and post evaluation system, and develop detailed implementation methods for high-tech products (services).

\subsection{Promoting Domestic Products}

On one hand, Chinese policies need to comply with the GPA framework and consider relevant policies that are outside its scope. On the other hand, it is not strict enough for China to justify and review imported products. If the procurers themselves guide the experts, do not understand market 
conditions, or the reviewing departments are not familiar, policy implementation on domestic product protection will be biased.

Therefore, the imported product list should be divided into three categories: allowed procurement, prohibited procurement, and strictly controlled procurement. For key developing industries with a higher proportion of imported products, the government should preferentially formulate allowed procurement lists and prohibited procurement lists to support local innovation and development.

\subsection{Improving Participation of Ministries and Committees in Policy Making}

Formulating PP policies that promote S\&T innovation requires the participation of several agencies. However, it has been noted that in general, a large number of agencies are not actively involved. The vast majority is below average with regard to policy making (either as a participant or as the chief). Agencies participate less and there is not much at stake for them. In addition, if the policy does not have a large coverage, its effectiveness may be discounted. In order for a PP policy on promotion of S\&T innovation in the country, it is important that the dominance of MOF is reduced. On the international stage, developed countries need to realize that MOF has intervened too much in PP policy formulation and a deep misunderstanding about government subsidies is highly possible. The MOF should appropriately decentralize policy-making to other relevant agencies in order to eliminate these unnecessary misunderstandings.

\section{Conclusions}

Based on analysis of the institutional structure of PP policies for promoting S\&T innovation, this article systematically sorts out policies at the national level, and interprets and analyzes those that belong to four different classifications. From the view of policy formulation frequencies, policy formulation agencies, chief agencies, and collaboration agencies, the article analyzes 34 practical policy texts, including 785 policy tool records. We point out that the various SC agencies should strengthen participation and domination so as to accomplish national policies with full integrity. Comparative analysis of the policies for China and the six countries was done on these four dimensions: energy-saving and environmentally friendly products, S\&T SMEs' development, high-tech products, and domestic products. Suggestions are provided as an objective reference for policymaking according to the discussion in Section 4.

First, we have accurately described the main structural features for Chinese sustainable PP policies on promoting S\&T innovation. Second, by applying the above-mentioned methods, we introduce a way to compare and analyze the differences and backgrounds of policy-making in different countries. Finally, the specific suggestions on sustainable PP are excellent references.

It is worth noting that, so far, few scholars have conducted an international comparative research on sustainable PP policies for promoting S\&T innovation. In this article, the method of classification cleaning data can help us to obtain a more accurate analysis scope. This article's research framework provides a new perspective for sustainable PP policies on promoting S\&T innovation, and could be applied to analyze other industry policies.

Author Contributions: All authors for publication approved the manuscript. X.W., Y.L. and Y.J. conceived and designed the study; X.W. collected the data; X.W. analyzed the data; X.W. wrote the article. X.W., Y.J. reviewed and edited the manuscript.

Funding: This research was funded by the National Key R\&D Program of China (Grant No. 2017YFB1401100), the National Natural Science Foundation of China (Grant No. 71573017, 71603019, L1724042), the Soft Science Research Plan of Henan (Grant No. 182400410184).

Acknowledgments: We are thankful for the support of CSAIM of BIT. We are thankful for the suggestions and efforts from the experts and editors.

Conflicts of Interest: The authors declare no conflict of interest. 


\section{Appendix A}

Table A1. The Related Laws.

\begin{tabular}{clcc}
\hline No. & \multicolumn{1}{c}{ Name } & Agency & Time \\
\hline 1 & $\begin{array}{l}\text { Tendering and Bidding Law of the People's } \\
\text { Republic of China }\end{array}$ & NPCSC & August 1999 \\
\hline 2 & $\begin{array}{l}\text { Government Procurement Law of the } \\
\text { People's Republic of China }\end{array}$ & NPCSC & June 2002 released; August 2014 amended \\
\hline 3 & $\begin{array}{l}\text { Law of the People's Republic of China on the } \\
\text { Promotion of Small and } \\
\text { Medium-Sized Enterprises }\end{array}$ & NPCSC & June 2002 released; September 2017 amended \\
\hline 4 & $\begin{array}{l}\text { Energy Conservation Law of the People's } \\
\text { Republic of China }\end{array}$ & NPCSC & November 1997 released; October 2016 amended \\
\hline 5 & $\begin{array}{l}\text { Budget Law of the People's Republic of China } \\
6\end{array}$ & $\begin{array}{l}\text { Environmental Protection Law of the } \\
\text { People's Republic of China }\end{array}$ & NPCSC \\
\hline 7 & $\begin{array}{l}\text { Law of the People's Republic of China on } \\
\text { Promoting the Transformation of Scientific } \\
\text { and Technological Achievements }\end{array}$ & NPCSC & December 1989 released; April 2014 amended \\
\hline 8 & $\begin{array}{l}\text { Law of the People's Republic of China on } \\
\text { Scientific and Technological Progress }\end{array}$ & NPCSC & October 1993 released; December 2007 amended \\
\hline
\end{tabular}

Table A2. Subclasses Retrieval Strategy.

\begin{tabular}{|c|c|c|}
\hline No. & Subclass & Retrieval Strategy \\
\hline 1 & Promoting Development of S\&T SMEs & 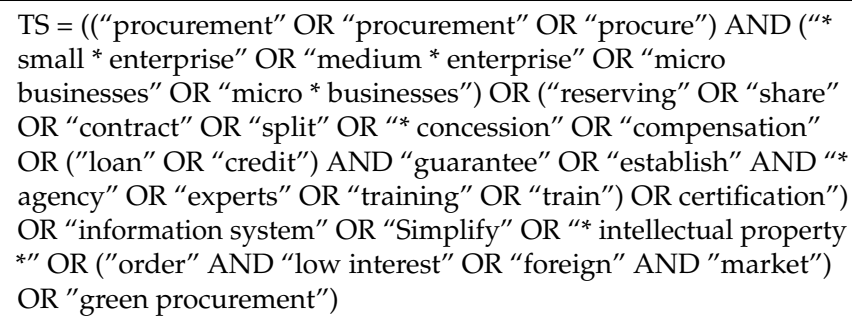 \\
\hline 2 & Promoting High-Tech Products & 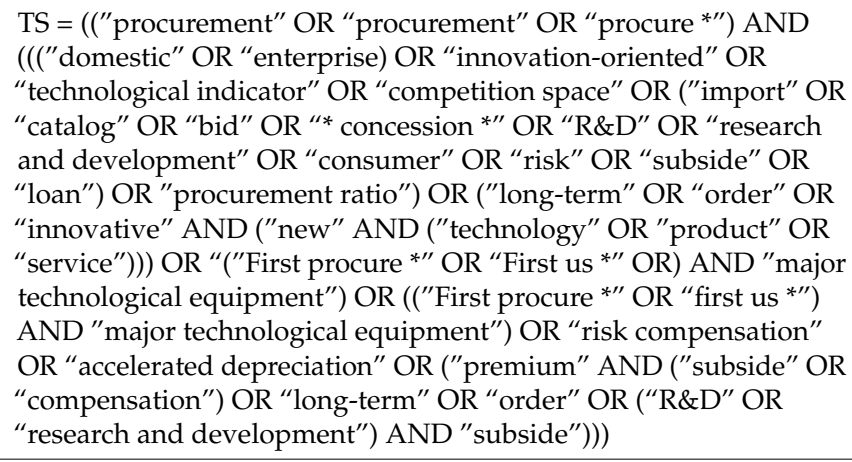 \\
\hline 3 & $\begin{array}{l}\text { Promoting Public Procurement of } \\
\text { Energy-saving and Environmentally } \\
\text { Friendly Products }\end{array}$ & $\begin{array}{l}\text { TS = (("procurement" OR "procurement" OR "procure") AND } \\
\text { ("energy-saving" OR "environmental protection" OR “green") AND } \\
\text { ("priority" OR "mandatory" OR "guide" OR “directory") OR } \\
\text { "standard" OR ("price" AND "concession" OR "reserving" OR } \\
\text { "share") OR "certification" OR "label" OR ("new energy" AND } \\
\text { "vehicle")) }\end{array}$ \\
\hline 4 & $\begin{array}{l}\text { Promoting Public Procurement of } \\
\text { Domestic Products }\end{array}$ & $\begin{array}{l}\text { TS = (("procurement" OR "procurement" OR "procure") AND } \\
\text { ("domestic" AND ("minimum" OR "share") OR ("Restriction" } \\
\text { AND ("national security" OR "public safety")) OR ("GPA" AND } \\
\text { "exception clause" OR "bid" AND ("threshold" OR "cost)) OR } \\
\text { "increase tariffs" OR ("imported" AND ("transfer" OR "service" OR } \\
\text { "compensation" OR "priority" OR "ban"))) }\end{array}$ \\
\hline
\end{tabular}


Table A3. The Related Plans of the SC.

\begin{tabular}{|c|c|c|c|c|}
\hline No. & Name & Agency $^{1}$ & Time & Additional \\
\hline 1 & $\begin{array}{l}\text { Outline of the National Medium- and Long-Term Plan for Science } \\
\text { and Technology (2006-2020) }\end{array}$ & SC & February 2006 & Running plan \\
\hline 2 & $\begin{array}{l}\text { The 11th Five Year Plan For the National Economic and Social } \\
\text { Development of People's Republic of China }\end{array}$ & SC & March 2006 & Disabled plan \\
\hline 3 & $\begin{array}{l}\text { The 12th Five Year Plan for the National Economic and Social } \\
\text { Development of People's Republic of China }\end{array}$ & SC & March 2011 & Disabled plan \\
\hline 4 & $\begin{array}{l}\text { The Thirteenth Five Year Plan for the National Economic and } \\
\text { Social Development of People's Republic of China }\end{array}$ & CCPCC, SC & March 2016 & Running plan \\
\hline 5 & Outline of National Development Strategy Driven by Innovation & CCPCC, SC & May 2016 & Running plan \\
\hline 6 & "13th Five-Year" National S\&T Innovation Plan & SC & July 2016 & Running plan \\
\hline 7 & $\begin{array}{l}\text { Notifications of Issuance on " } 13 \text { th Five-Year" National Strategic } \\
\text { Emerging Industry Development Plan }\end{array}$ & SC & November 2016 & Running plan \\
\hline
\end{tabular}

${ }^{1}$ In China, the plan is issued with a five-year cycle. The plan and policy formulated by subordinates will be based on the upper-level laws. Once the plan or policy faces new requirements, they would be adjusted or revised.

Table A4. The Regulations of the SC.

\begin{tabular}{clccc}
\hline No. & \multicolumn{1}{c}{ Name } & Agency & Time & Additional \\
\hline 1 & $\begin{array}{l}\text { The Regulations on the Implementation on Tenders and } \\
\text { Bids of the People's Republic of China }\end{array}$ & SC & $\begin{array}{c}\text { December 2011 } \\
\text { released; March } \\
\text { 2017 amended }\end{array}$ \\
\hline 2 & $\begin{array}{l}\text { The Regulations on the Implementation of the Public } \\
\text { procurement Law of the People's Republic of China }\end{array}$ & SC & January 2015 \\
\hline
\end{tabular}

Table A5. The Related Plans of the Departments.

\begin{tabular}{ccccc}
\hline No. & Name & Agency & Time & Additional \\
\hline 1 & "11th Five-Year" National S\&T Development Plan & MOST & October 2006 & Disabled plan \\
2 & "12th Five-Year" National S\&T Development Plan & MOST & July 2011 & Disabled plan \\
\hline
\end{tabular}

Table A6. Public Procurement to Promote S\&T Innovation for the Lower Level.

\begin{tabular}{|c|c|c|c|c|}
\hline No. & Name & Agency $^{1}$ & Time & Additional \\
\hline 1 & $\begin{array}{l}\text { Management Measures of Public procurement of Goods and } \\
\text { Tendering and Bidding of Services }\end{array}$ & $\mathrm{MOF}$ & $\begin{array}{l}\text { 2004-08 released } \\
\text { July } 2017 \text { amended }\end{array}$ & \\
\hline 2 & $\begin{array}{l}\text { Opinions on the Implementation of Public Procurement for } \\
\text { Energy Saving Products }\end{array}$ & MOF, NDRC & December 2004 & \\
\hline 3 & $\begin{array}{l}\text { Advice on the Implementation of Public Procurement for } \\
\text { WLAN Products }\end{array}$ & MOF, NDRC, MIIT & December 2005 & \\
\hline 4 & $\begin{array}{l}\text { The Decision on Implementing the Program of Science and } \\
\text { Technology to Enhance the Ability of Independent Innovation }\end{array}$ & CCPCC, SC & January 2006 & \\
\hline 5 & $\begin{array}{l}\text { Notifications of Issuance on Implementation of Some } \\
\text { Supporting Policies for “Outline of the National Medium- and } \\
\text { Long-Term Plan for Science and Technology (2006-2020)" }\end{array}$ & SC & February 2006 & \\
\hline 6 & $\begin{array}{l}\text { Some Opinions on Implementation of Public procurement } \\
\text { Policy to Promote Independent Innovation }\end{array}$ & MOF & June 2006 & \\
\hline 7 & $\begin{array}{l}\text { Opinions on the Implementation of Public Procurement of } \\
\text { Environmental Marking Products }\end{array}$ & MOF, MEP & October 2006 & \\
\hline 8 & $\begin{array}{l}\text { Management Methods on Identification of National } \\
\text { Independent Innovation Products (Trial) }\end{array}$ & MOST, NDRC, MOF & $\begin{array}{l}\text { December } 2006 \\
\text { released; July } 2011 \\
\text { abolished }\end{array}$ & \\
\hline 9 & $\begin{array}{l}\text { Management Methods on Contract of Independent } \\
\text { Innovation Products }\end{array}$ & MOF & $\begin{array}{l}\text { April } 2007 \text { released; } \\
\text { July } 2011 \text { abolished }\end{array}$ & \\
\hline 10 & $\begin{array}{l}\text { Management Methods on Evaluation of Independent } \\
\text { Innovation Products }\end{array}$ & MOF & $\begin{array}{l}\text { April } 2007 \text { released; } \\
\text { July } 2011 \text { abolished }\end{array}$ & \\
\hline 11 & $\begin{array}{l}\text { Management Methods on Budget of Independent Innovation } \\
\text { Products }\end{array}$ & MOF & $\begin{array}{l}\text { April } 2007 \text { released; } \\
\text { July } 2011 \text { abolished }\end{array}$ & \\
\hline
\end{tabular}


Table A6. Cont.

\begin{tabular}{|c|c|c|c|c|}
\hline No. & Name & Agency $^{1}$ & Time & Additional \\
\hline 12 & $\begin{array}{l}\text { Notice on the Establishment of Government Compulsory } \\
\text { Procurement System for Energy Saving Products }\end{array}$ & SCGO & July 2007 & \\
\hline 13 & $\begin{array}{l}\text { Notice on Implementing Government Compulsory } \\
\text { Procurement of Energy Saving Products Symposium }\end{array}$ & MOFGO & December 2007 & \\
\hline 14 & $\begin{array}{l}\text { Management Methods on Public Procurement of Imported } \\
\text { Products }\end{array}$ & MOF & December 2007 & \\
\hline 15 & $\begin{array}{l}\text { Management Methods on First Procurement or First Order of } \\
\text { Public Procurement of Independent Innovation Products }\end{array}$ & MOF & December 2007 & \\
\hline 16 & $\begin{array}{l}\text { Management Methods on Test Project or Demonstration } \\
\text { Project of the First (set) Major Technique Equipment }\end{array}$ & $\begin{array}{l}\text { NDRC, MOST, MOF, } \\
\text { SASTIND }\end{array}$ & January 2008 & \\
\hline 17 & $\begin{array}{l}\text { Notifications on Public Procurement Management of } \\
\text { Imported Products }\end{array}$ & MOFGO & July 2008 & \\
\hline 18 & Opinions on Further Promoting the Development of SMEs & SC & September 2009 & \\
\hline 19 & $\begin{array}{l}\text { Public Notice of Public Consultation on " Management } \\
\text { Methods on Public Procurement of Domestic Product } \\
\text { (Solicitation Draft)" }\end{array}$ & $\begin{array}{l}\text { MOF, MOFCOM, } \\
\text { NDRC, GAC }\end{array}$ & May 2010 & \\
\hline 20 & $\begin{array}{l}\text { Notifications Issuance on Provisions of Classification Criteria } \\
\text { of SMEs }\end{array}$ & $\begin{array}{l}\text { MIIT, NBS, NDRC, } \\
\text { MOF }\end{array}$ & June 2011 & \\
\hline 21 & $\begin{array}{l}\text { Notice on Carrying Out the Pilot Work of Public } \\
\text { procurement's Credit Guarantee }\end{array}$ & MOF & September 2011 & \\
\hline 22 & $\begin{array}{l}\text { Notice on Cleaning the Documents of Innovation Policies } \\
\text { Related to Provision of Public Procurement's Preferences }{ }^{2}\end{array}$ & SCGO & November 2011 & $\begin{array}{l}\text { Related to } \\
\text { abolished } \\
\text { policies }\end{array}$ \\
\hline 23 & $\begin{array}{l}\text { Interim Measures on Public procurement to Promote the } \\
\text { Development of SMEs }\end{array}$ & MOF, MIIT & December 2011 & \\
\hline 24 & $\begin{array}{l}\text { Opinions on Further Support For the Healthy Development of } \\
\text { Small and Micro Enterprises }\end{array}$ & SC & April 2012 & \\
\hline 25 & $\begin{array}{l}\text { Opinions on Speeding up the Development of Energy Saving } \\
\text { and Environmental Protection Industry }\end{array}$ & $\mathrm{SC}$ & August 2013 & \\
\hline 26 & $\begin{array}{l}\text { Notice on the Continuation of Promotion and Application of } \\
\text { New Energy Vehicles }\end{array}$ & $\begin{array}{l}\text { MOF, MOST, MIIT, } \\
\text { NDRC }\end{array}$ & September 2013 & \\
\hline 27 & $\begin{array}{l}\text { Management Methods on Public procurement } \\
\text { Without Bidding }\end{array}$ & MOF & December 2013 & \\
\hline 28 & $\begin{array}{l}\text { Guidance Opinions on Accelerating Promotion and } \\
\text { Application of New Energy Vehicles }\end{array}$ & SCGO & July 2014 & \\
\hline 29 & $\begin{array}{l}\text { Interim Management Measures on Competitive Consultations } \\
\text { of Public procurement }\end{array}$ & MOF & December 2014 & \\
\hline 30 & $\begin{array}{l}\text { Management Methods on Public Procurement of Government } \\
\text { and Social Capital Cooperation Project }\end{array}$ & MOF & December 2014 & \\
\hline 31 & $\begin{array}{l}\text { Notice on the Pilot Work of Insurance Compensation } \\
\text { Mechanism of the First (set) Major Technique Equipment }\end{array}$ & MOF, MIIT, CIRC & February 2015 & \\
\hline 32 & $\begin{array}{l}\text { Opinions on Deepening the Reform of Institutional } \\
\text { Mechanism and Accelerating Implementation of Innovation } \\
\text { Driven Development Strategy }\end{array}$ & SC & March 2015 & \\
\hline 33 & $\begin{array}{l}\text { Supplementary Notice on the Provisional Measures for } \\
\text { "Interim Management Measures on Competitive } \\
\text { Consultations of Public Procurement" }\end{array}$ & MOF & July 2015 & \\
\hline 34 & $\begin{array}{l}\text { Notifications of Issuance on "Venture China" Leading Project } \\
\text { in Zhongguancun Science Park }\end{array}$ & MOST & September 2015 & \\
\hline 35 & $\begin{array}{l}\text { Notifications of Issuance on the Key Points of Public } \\
\text { Procurement In } 2016\end{array}$ & MOF & February 2016 & \\
\hline 36 & $\begin{array}{l}\text { Management Methods on Public Procurement of MOT's } \\
\text { Direct Subordinate }\end{array}$ & MOT & December 2016 & \\
\hline 37 & Management Methods on Public Procurement of MOA & MOA & $\begin{array}{l}\text { December } 2003 \\
\text { released March } \\
2017 \text { amended }\end{array}$ & \\
\hline
\end{tabular}


Table A6. Cont.

\begin{tabular}{clcc}
\hline No. & \multicolumn{1}{c}{ Name } & Agency ${ }^{\mathbf{1}}$ & Time \\
\hline 38 & $\begin{array}{l}\text { Adjustment Notice on the Twentieth List of Public } \\
\text { Procurement for Environmental Symbol Products }\end{array}$ & MOF, MEP & July 2017 \\
\hline 39 & $\begin{array}{l}\text { Adjustment Notice on the Twenty-Second List of Public } \\
\text { Procurement for Energy Saving Products }\end{array}$ & MOF, NDRC & July 2017 \\
\hline
\end{tabular}

Notes: ${ }^{1}$ The abbreviation of agencies is as follows: CCPCC—Central Committee of the Chinese Communist Party; CIRC — China Insurance Regulatory Commission; GAC—-General Administration of Customs; MEP—-the Ministry of Environmental Protection; MOA-Ministry of Agriculture; MOF-Ministry of Finance; MOFCOM-Ministry of Commerce; MIIT—Ministry of Industry and Information Technology; MOST-Ministry of Science and Technology; MOT-Ministry of Transport; NBS-National Bureau of Statistics; NDRC—National Development and Reform Commission; SASTIND—State Administration of Science; Technology and Industry for National Defense; SC—State Council; and SCGO-General Office of State Council. ${ }^{2}$ The policy issued to abolish some related policies, including the eighth, ninth, tenth, and eleventh. ${ }^{3}$ Since 2006 , once or twice a year, the MOF and MEP jointly adjusted and released the public procurement list of environmental labeling products. Since 2004, once or twice a year, the MOF and NDRC jointly adjusted and released the public procurement list of energy-saving products. The public procurement activities carried out after the current list should comply with the current list of environmental protection or energy-saving products. The public procurement activities carried out before the issuance of the current list, but have not yet entered the evaluation stage, may comply with the previous list or the current list, according to the procurement documents. Whereas, if the procurement documents do not stipulate, then the previous list and current list can play simultaneously.

Table A7. Laws on Government Procurement in the U.S. (Part).

\begin{tabular}{cl}
\hline NO. & \\
\hline 1 & Federal Acquisition Regulation \\
2 & Buy American Act \\
3 & Federal Property and Administrative Services Act \\
4 & NASA Acquisition Regulation \\
5 & The Small Business Act \\
6 & Competition in Contracting Act \\
7 & Federal Acquisition Regulation System \\
8 & Make it in America Act \\
9 & American Renewable Energy and Efficiency Act \\
10 & The Small Business Innovation Research and Small Business Technology Transfer Improvements Act \\
\hline
\end{tabular}

Table A8. Laws on Government Procurement in Japan (Part).

\begin{tabular}{cl}
\hline NO. & \multicolumn{1}{c}{ Name } \\
\hline 1 & Accounting Act \\
2 & Local Government Act \\
3 & Contractual Business Transactions Regulation \\
4 & SMEs Basic Act \\
5 & Ensuring SMEs Order of Governments and Other Public Agencies \\
6 & Guideline on Government Procurement Procedures of Goods \\
7 & Executive Order on Implementation of Local Government Act \\
8 & Market Access on Good of Government Procurement \\
9 & Procurement Measures on Electronic Communications Equipment and Service in Japanese Public Sector \\
10 & Procurement Measures on Medical Technology Products and Services in Japanese Public Sector \\
11 & Regulation on Government Procurement (Service Area) \\
12 & Green Procurement Act \\
\hline
\end{tabular}


Table A9. Laws on Government Procurement in Germany (Part).

\begin{tabular}{cl}
\hline NO. & \\
\hline 1 & New Law of Tendering and Bidding \\
2 & Anti-Restriction Competition \\
3 & Directive on the Coordination of Procurement Procedures of Public Works, Goods and Services \\
4 & Directive on the Coordination of Services Procurement Procedures of Water Supply, Energy, \\
5 & Transportation and Postal Service \\
6 & Public Procurement Directive \\
7 & Federal Budget Regulation \\
8 & Pubcontracting and Contracting of Goods and Services \\
9 & Public Pricing Regulation \\
10 & Act on Circular Economy and Waste Management \\
\hline
\end{tabular}

Table A10. Laws on Government Procurement in South Korean (Part).

\begin{tabular}{cl}
\hline NO. & \\
\hline 1 & Government Contract Act \\
2 & Government Investment Agency Act \\
3 & Local Finance Act \\
4 & Implementation Regulations on Government Contract Act \\
5 & Basic Act on Electronic Transactions \\
6 & Electronic Signature Act \\
7 & Excellent Product Procurement System \\
8 & Procurement Business Act \\
9 & Management Provisions on Designated Procurement of Excellent Goods \\
10 & Low Carbon Green Growth Basic Act \\
\hline
\end{tabular}

Table A11. Laws on Government Procurement in the UK (Part).

\begin{tabular}{cl}
\hline NO. & \multicolumn{1}{c}{ Name } \\
\hline 1 & Public Contracts Regulations \\
2 & Utilities Contracts Regulations \\
3 & Local Government Act \\
4 & The Contracting-out Regulations \\
5 & The Public Contracts and Utilities Contracts Regulations \\
6 & The Public Procurement Regulations \\
7 & Green Energy Act \\
8 & The Green Deal Regulations \\
9 & Small Business, Enterprise and Employment Act \\
10 & Climate Change and Sustainable Energy Act \\
\hline
\end{tabular}

Note: http://www.legislation.gov.uk/. 
Table A12. Laws on Government Procurement in France (Part).

\begin{tabular}{cl}
\hline NO. & \\
\hline 1 & Government Procurement Code \\
2 & Economic Modernization Act \\
3 & General Ordinance \\
4 & Budget Act \\
5 & Accounting Act \\
6 & Tax Act \\
7 & Rule on Contracting and Subcontracting of General Project \\
8 & Act on Statistics of Government Procurement Contracts \\
9 & Act on Entrustment and Authorization of the National Government Procurement Contract \\
10 & Act on Procurement Contracts Involved Sectors of the Water, Energy, Transportation and \\
& Telecommunications \\
\hline
\end{tabular}

Note: http://www.assemblee-nationale.fr/.

Table A13. Laws on Government Procurement in EU (Part).

\begin{tabular}{cl}
\hline NO. & \multicolumn{1}{c}{ Name } \\
\hline 1 & Concerning the Coordination of Procedures for the Award of Public Works Contracts \\
\hline 2 & Relating to the Coordination of Procedures for the Award of Public Service Contracts \\
\hline 3 & $\begin{array}{l}\text { The Coordination of Procedures for the Award of Public Works Contracts, Public Supply } \\
\text { Contracts and Public Service Contracts }\end{array}$ \\
\hline 4 & $\begin{array}{l}\text { Coordinating the Procurement Procedures of Entities Operating in the Water, Energy, } \\
\text { Transport and Postal Services Sectors }\end{array}$ \\
\hline & $\begin{array}{l}\text { On the Coordination of the Laws, Regulations And Administrative Provisions Relating to } \\
\text { the Application of Review Procedures to the Award of Public Supply and Public Works } \\
\text { Contracts }\end{array}$ \\
\hline 6 & $\begin{array}{l}\text { Coordinating the Laws, Regulations and Administrative Provisions Relating to the } \\
\text { Application of Community Rules on the Procurement Procedures of Entities Operating in } \\
\text { Water, Energy, Transport and Telecommunications Sectors }\end{array}$ \\
\hline
\end{tabular}

\section{References}

1. 17 Goals to Transform Our World. Available online: https://www.un.org/sustainabledevelopment/ (accessed on 20 March 2018).

2. Goal 12: Ensure Sustainable Consumption and Production Patterns. Available online: https://www.un.org/ sustainabledevelopment/sustainable-consumption-production/ (accessed on 20 March 2018).

3. Brooks, A.; Rich, H. Sustainable construction and socio-technical transitions in London's mega-projects. Geogr. J. 2016, 182, 395-405. [CrossRef]

4. Diofasi-Kovacs, O.; Valko, L. Furthering sustainable development: The implementation of Green Procurement in Central and Eastern Europe Methods and Experiences from Hungarian Public and Private Organizations. Probl. Ekorozw. 2015, 10, 115-126.

5. Correia, F.; Howard, M.; Hawkins, B.; Pye, A.; Lamming, R. Low carbon procurement: An emerging agenda. J. Purch. Supply Manag. 2013, 19, 58-64. [CrossRef]

6. Song, H.F.; Rong-Ping, M.U.; Ren, Z.B. Study on correlation between the government procurement policy and the related implemented rules. Stud. Sci. Sci. 2011, 29, 291-298.

7. December 2016 Import and Export Product Gross Value Table Divided by Country (Region). Available online: http:/ / www.customs.gov.cn/publish/portal0/tab49667/info837842.htm (accessed on 20 March 2018).

8. Ferri, F. Sustainable Public Procurement under EU Law: New Perspectives on the State as Stakeholder. Common Mark. Law Rev. 2017, 54, 1265-1267.

9. Wang, G.; Li, X.; Zhang, B.; Meng, D.; Gao, G. Innovation policies and mechanisms: Evidences from four industries in China. Sci. Res. Manag. 2015, 33, 1-10. 
10. Xu, S.; Chu, C.; Ju, M.; Shao, C. System Establishment and Method Application for Quantitatively Evaluating the Green Degree of the Products in Green Public Procurement. Sustainability 2016, 8, 941. [CrossRef]

11. Yang, W. International Comparison and Reference of Government Green Procurement Legal System. Mod. Econ. Res. 2013, 23, 88-92.

12. Gee, S.; Uyarra, E. A role for public procurement in system innovation: The transformation of the Greater Manchester (UK) waste system. Technol. Anal. Strateg. Manag. 2013, 25, 1175-1188. [CrossRef]

13. Grandia, J. The role of change agents in sustainable public procurement projects. Public Money Manag. 2015, 35, 119-126. [CrossRef]

14. He, Z.X.; Xu, S.C.; Li, Q.B.; Zhao, B. Factors That Influence Renewable Energy Technological Innovation in China: A Dynamic Panel Approach. Sustainability 2018, 10, 124. [CrossRef]

15. Grose, J.; Bennallick, M.; Nichols, A.; Pahl, S.; Richardson, J. Facilitating Sustainable Waste Management Behaviors Within the Health Sector: A Case Study of the National Health Service (NHS) in Southwest England, UK. Sustainability 2012, 4, 630-642. [CrossRef]

16. Rolfstam, M. Public procurement as an innovation policy tool: The role of institutions. Sci. Public Policy 2012, 36, 349-360. [CrossRef]

17. Kunzlik, P. Green Public Procurement-European Law, Environmental Standards and 'What To Buy' Decisions. J. Environ. Law 2013, 25, 173-202. [CrossRef]

18. Essig, M. Public procurement of innovation: Empirical evidence from EU public authorities on barriers for the promotion of innovation. Innov. Eur. J. Soc. Sci. Res. 2015, 28, 282-292.

19. Bruno, T.; Gelderman, C.J.; Lambrechts, W.; Semeijn, J. The promise of Best Value Procurement: Governance and (in)stability of specifications within an innovative biogas project. J. Clean. Prod. 2018, 172, 1465-1475. [CrossRef]

20. Iimi, A. Multidimensional Auctions for Public Energy Efficiency Projects: Evidence from Japanese Esco Market. Rev. Ind. Organ. 2016, 49, 491-514. [CrossRef]

21. Kumar, R.R.; Patel, A.; Singh, M. Effect of Procurement Policy on aid Inflows in the Pacific: Accounting for Economic Growth and Financial Development in Fiji. Inz. Ekon. 2017, 28, 505-513. [CrossRef]

22. Schopf, J.C. Following the Money to Determine the Effects of Democracy on Corruption: The Case of Korea. J. East Asian Stud. 2011, 11, 1-39. [CrossRef]

23. Lopert, R.; Gleeson, D. The High Price of "Free" Trade: U.S. Trade Agreements and Access to Medicines. J. Law Med. Ethics 2013, 41, 199-223. [CrossRef] [PubMed]

24. Cardoza, G.; Fornes, G.; Li, P.; Xu, N.; Xu, S. China goes global: Public policies' influence on small- and medium-sized enterprises' international expansion. Asia Pac. Bus. Rev. 2015, 21, 188-210. [CrossRef]

25. Flynn, A.; Davis, P. The policy-practice divide and SME-friendly public procurement. Environ. Plan. C 2016, 34, 559-578. [CrossRef]

26. Loader, K. Is public procurement a successful small business support policy? A review of the evidence. Environ. Plan. C 2013, 31, 39-55. [CrossRef]

27. Sack, D. Europeanization and Party Politics in German Federal States-The Jurisdiction of the European Court of Justice and the Amendments of Public Procurement Regulation. Polit. Vierteljahresschr. 2010, 51, 619-642. [CrossRef]

28. Reijonen, H.; Tammi, T.; Saastamoinen, J. SMEs and public sector procurement: Does entrepreneurial orientation make a difference? Int. Small Bus. J. 2016, 34, 468-486. [CrossRef]

29. Loader, K. Small- and medium-sized enterprises and public procurement: A review of the UK coalition government's policies and their impact. Environ. Plan. C-Politics Space 2018, 36, 47-66. [CrossRef]

30. Edquist, C.; Zabala-Iturriagagoitia, J.M. Pre-commercial procurement: A demand or supply policy instrument in relation to innovation? $R$ \& D Manag. 2015, 45, 147-160.

31. Antony, J.; Setijono, D.; Dahlgaard, J.J. Lean Six Sigma and Innovation-An exploratory study among UK organisations. Total Qual. Manag. Bus. 2016, 27, 124-140. [CrossRef]

32. Whyles, G.; van Meerveld, H.; Nauta, J. Forward Commitment Procurement: A practical methodology that helps to manage risk in procuring innovative goods and services. Innov. Eur. J. Soc. Sci. Res. 2015, 28, 293-311. [CrossRef]

33. Polzin, F.; von Flotow, P.; Nolden, C. Modes of governance for municipal energy efficiency services The case of LED street lighting in Germany. J. Clean. Prod. 2016, 139, 133-145. [CrossRef] 
34. Amaral, M.; Saussier, S.; Yvrande-Billon, A. Auction procedures and competition in public services: The case of urban public transport in France and London. Util. Policy 2009, 17, 166-175. [CrossRef]

35. Barberio, A.M.; Sumar, N.; Trieu, K.; Lorenzetti, D.L.; Tarasuk, V.; Webster, J.; Campbell, N.R.C.; McLaren, L. Population-level interventions in government jurisdictions for dietary sodium reduction: A Cochrane Review. Int. J. Epidemiol. 2017, 46, 1551-1563. [CrossRef] [PubMed]

36. Leger, A.; Oueslati, W.; Salanie, J. Public tendering and green procurement as potential drivers for sustainable urban development: Implications for landscape architecture and other urban design professions. Landsc. Urban Plan 2013, 116, 13-24. [CrossRef]

37. Ishii, R. Bid Roundness Under Collusion in Japanese Procurement Auctions. Rev. Ind. Organ. 2014, 44, 241-254. [CrossRef]

38. Sorte, W.F. Nurturing domestic firms through public procurement: A comparison between Brazil and Japan. Public Policy Adm. 2016, 31, 29-50.

39. Cho, J.I.Y. Antitrust Implications of Defense Development Projects in South Korea: The Case of the KSS-III Project. Korean J. Def. Anal. 2013, 25, 37-57.

40. Shorten, T.; Taylor, M.; Spicer, N.; Mounier-Jack, S.; McCoy, D. The International Health Partnership Plus: Rhetoric or real change? Results of a self-reported survey in the context of the 4th high level forum on aid effectiveness in Busan. Glob. Health 2012, 8, 13. [CrossRef] [PubMed]

41. Horng, D.C. Reshaping the EU's FTA Policy in a Globalizing Economy: The Case of the EU-Korea FTA. J. World Trade 2012, 46, 301-326.

42. Zhang, G.Q.; Xu, Y.M.; Zhang, J. Consumer-Oriented Policy towards Diffusion of Electric Vehicles: City-Level Evidence from China. Sustainability 2016, 8, 1343. [CrossRef]

43. Chow, D.C.K. China's Indigenous Innovation Policies and the World Trade Organization. Northwest. J. Int. Law Bus. 2013, 34, 81-124.

44. Gong, T.; Zhou, N. Corruption and marketization: Formal and informal rules in Chinese public procurement. Regul. Gov. 2015, 9, 63-76. [CrossRef]

45. Li, Y.C.; Georghiou, L. Signaling and accrediting new technology: Use of procurement for innovation in China. Sci. Public Policy 2016, 43, 338-351. [CrossRef]

46. Bitzinger, R.A. The eclipse of Taiwan's defense industry and growing dependencies on the United States for advanced armaments: Implications for US-Taiwan-Chinese relations. Issues Stud. 2002, 38, 101-129.

47. Dixon, P.B.; Rimmer, M.T.; Waschik, R.G. Evaluating the effects of local content measures in a CGE model: Eliminating the US Buy America(n) programs. Econ. Model 2018, 68, 155-166. [CrossRef]

48. Slavtchev, V.; Wiederhold, S. Does the Technological Content of Government Demand Matter for Private R\&D? Evidence from US States. Am. Econ. J.-Macroecon. 2016, 8, 45-84.

49. Aspey, E.; Craven, R. Regulating Complex Contracting: A Socio-legal Study of Decision-Making Under EU and UK law. Mod. Law Rev. 2018, 81, 191-221. [CrossRef]

50. Ladi, S.; Tsarouhas, D. International diffusion of regulatory governance: EU actorness in public procurement. Regul. Gov. 2017, 11, 388-403. [CrossRef]

51. Murray, J.G. Debate: UK public procurement 2014. Public Money Manag. 2014, 34, 244-246. [CrossRef]

52. Seikel, D. Class struggle in the shadow of Luxembourg. The domestic impact of the European Court of Justice's case law on the regulation of working conditions. J. Eur. Public Policy 2015, 22, 1166-1185. [CrossRef]

53. Brezovnik, B.; Oplotnik, Z.J.; Vojinovic, B. (De)Centralization of Public Procurement at the Local Level in the Eu. Transylv. Rev. Adm. Sci. 2015, 11, 37-52.

54. Hattori, T. Determinants of the number of bidders in the competitive procurement of electricity supply contracts in the Japanese public sector. Energ Econ. 2010, 32, 1299-1305. [CrossRef]

55. Hosoe, N.; Takagi, S. Retail power market competition with endogenous entry decision-An auction data analysis. J. Jpn. Int. Econ. 2012, 26, 351-368. [CrossRef]

56. Shingal, A. Services procurement under the WTO's Agreement on Government Procurement: Whither market access? World Trade Rev. 2011, 10, 527-549. [CrossRef]

57. Chung, H.S. Government Procurement in the United States-Korea Free Trade Agreement: Great Opportunities for Both Sides? Northwest. J. Int. Law Bus. 2014, 34, 299-335.

58. Wen, Z.Y. Government Purchase of Services in China: Similar Intentions, Different Policy Designs. Public Adm. Dev. 2017, 37, 65-78. [CrossRef] 
59. Bertone, E.; Stewart, R.A.; Sahin, O.; Alam, M.; Zou, P.X.W.; Buntine, C.; Marshall, C. Guidelines, barriers and strategies for energy and water retrofits of public buildings. J. Clean. Prod. 2018, 174, 1064-1078. [CrossRef]

60. Bo, X.; Chan, A.P.C. Investigation of Barriers to Entry into the Design-Build Market in the People's Republic of China. J. Constr. Eng. Manag. ASCE 2012, 138, 120-127. [CrossRef]

61. Liu, Y.; Yan, Z.; Cheng, Y.-J.; Ye, X.-T. The Policy Mechanism and Empirical Study on Using Government Procurement to Promote Technological Innovation: The Case of Beijing. China Soft Sci. 2017, 31, 9-20.

62. Li, J.; Zhu, C. On Government Procurement Policy System to Promot Independent Innovation. Forum Sci. Technol. China 2015, 31, 15-19.

63. Bakirtas, D.; Aysu, A. Public Procurement in the Framework of Demand Side Innovation Policy: Theory and Examples of Practice. Amme Idaresi Derg. 2017, 50, 143-189.

64. Song, H.; Zhang, S. China's government procurement policy system construction and development for innovation product. Stud. Sci. Sci. 2014, 32, 1639-1645.

65. Torrecillas, C.; Fischer, B.B.; Sanchez, A. The dual role of R\&D expenditures in European Union's member states: Short- and long-term prospects. Innov. Eur. J. Soc. Sci. Res. 2017, 30, 433-454.

66. Coe, N.M. The externalisation of producer services debate: The UK computer services sector. Serv. Ind. J. 2000, 20, 64-81. [CrossRef]

67. Kim, Y.S. Domestic contexts for response to global HIV / AIDS in France: Perception, media role and civil society. Int. Politics 2016, 53, 343-360. [CrossRef]

68. Olykke, G.S. Public Procurement and the EU Competition Rules. Common Mark. Law Rev. 2011, 48, $2122-2124$.

69. Lember, V.; Kattel, R.; Kalvet, T. How Governments Support Innovation through Public Procurement: Comparing Evidence from 11 Countries. In Public Procurement, Innovation and Policy; Springer: Berlin/Heidelberg, Germany, 2014; pp. 287-309.

70. Knutsson, H.; Thomasson, A. Innovation in the Public Procurement Process. Public Manag. Rev. 2014, 16, 242-255. [CrossRef]

71. Milosavljevic, M.; Milanovic, N.; Benkovic, S. Politics, Policies and Public Procurement Efficiency: A Quantitative Study of 25 European Countries. Lex Localis 2016, 14, 537-558. [CrossRef]

72. Cruz, C.O.; Marques, R.C. Integrating Infrastructure and Clinical Management in PPPs for Health Care. J. Manag. Eng. 2013, 29, 471-481. [CrossRef]

73. Denis, A.; Mergaert, L.; Fostier, C.; Cleemput, I.; Simoens, S. A comparative study of European rare disease and orphan drug markets. Health Policy 2010, 97, 173-179. [CrossRef] [PubMed]

74. Wirtz, V.J.; Santa-Ana-Tellez, Y.; Trout, C.H.; Kaplan, W.A. Allocating scarce financial resources for HIV treatment: Benchmarking prices of antiretroviral medicines in Latin America. Health Policy Plan. 2012, 27, 638-648. [CrossRef] [PubMed]

75. Placek, M. The Effects of Decentralization on Efficiency in Public Procurement: Empirical Evidence for the Czech Republic. Lex Localis 2017, 15, 67-92.

76. Tiryakioglu, M.; Yulek, M.A. Development-based public procurement policies: A selective survey of literature, cross-country policy experience and the Turkish experience. Innov. Eur. J. Soc. Sci. Res. 2015, 28, 344-359. [CrossRef]

77. Cappellaro, G.; Fattore, G.; Torbica, A. Funding health technologies in decentralized systems: A comparison between Italy and Spain. Health Policy 2009, 92, 313-321. [CrossRef] [PubMed]

78. Hestermeyer, H.P.; Nielsen, L. The Legality of Local Content Measures under WTO Law. J. World Trade 2014, $48,553-591$.

79. Vecchiato, R.; Roveda, C. Foresight for public procurement and regional innovation policy: The case of Lombardy. Res. Policy 2014, 43, 438-450. [CrossRef]

80. Du, H.B.; Wei, L.X.; Brown, M.A.; Wang, Y.Y.; Shi, Z. A bibliometric analysis of recent energy efficiency literatures: An expanding and shifting focus. Energy Effic. 2013, 6, 177-190. [CrossRef]

81. Yu, X.; Li, M.; Kim, K.A.; Chung, J.; Ryu, K.H. Emerging Pattern-Based Clustering of Web Users Utilizing a Simple Page-Linked Graph. Sustainability 2016, 8, 239. [CrossRef]

82. Kim, G.; Lee, J.; Jang, D.; Park, S. Technology Clusters Exploration for Patent Portfolio through Patent Abstract Analysis. Sustainability 2016, 8, 1252. [CrossRef]

83. Kramer, O. Scikit-Learn. Stud. Big Data 2016, 20, 45-53. 
84. Abraham, A.; Pedregosa, F.; Eickenberg, M.; Gervais, P.; Mueller, A.; Kossaifi, J.; Gramfort, A.; Thirion, B.; Varoquaux, G. Machine learning for neuroirnaging with scikit-learn. Front. Neuroinform. 2014, 8, 14. [CrossRef] [PubMed]

85. Pedregosa, F.; Varoquaux, G.; Gramfort, A.; Michel, V.; Thirion, B.; Grisel, O.; Blondel, M.; Prettenhofer, P.; Weiss, R.; Dubourg, V.; et al. Scikit-learn: Machine Learning in Python. J. Mach. Learn. Res. 2011, 12, 2825-2830.

86. De Lima, R.A.; Velho, L.M.L. S.; de Faria, L.I.L. Bibliometrics and “evaluation” of scientific activity: A study of the h-index. Perspect. Cienc. Inf. 2012, 17, 3-17.

87. Ye, X.T.; Liu, Y.; Porter, A.L. International collaborative patterns in China's nanotechnology publications. Int. J. Technol. Manag. 2012, 59, 255-272. [CrossRef]

(c) 2018 by the authors. Licensee MDPI, Basel, Switzerland. This article is an open access article distributed under the terms and conditions of the Creative Commons Attribution (CC BY) license (http://creativecommons.org/licenses/by/4.0/). 